\title{
Articulating Journalists' Emotional Experiences of Crisis: Touching Down
}

Revived by the curiosity, James pulled out his computer again and turned on a movie player. He had long planned to watch Viggo Mortensen's reading of Albert Camus' speech "The Human Crisis," written in 1946 (Camus 2016). The flight seemed to be a perfect opportunity, the only opportunity. He put on his headphones and plunged into the materialtechnological solution.

To do justice to James' feelings, thoughts, and primarily to the conditions that (were supposed to) shape (d) them, the analysis requires to make a few final steps. The previous chapter illustrated that and in which sense emotions are to a large extent culturally determined, defined, and shaped practices of feeling and thinking (Rosaldo 1984; Scheer 2012; ScheperHughes and Lock 1987). But a concept that seems to be most intrinsic to the modern Western culture, whatever stance one adopts (e.g. Beck 1992; Foucault 1978; Heidegger 1977; Van Loon 2002; Williams 1974), is technology. One more crucial question thus arises: In which ways does technology, constitutively entangled with human beings (Orlikowski 2007), articulate journalists' emotional experience of crisis?

In recent media studies, technology has been thought as an assemblage of people, technological devices, buildings, texts, meanings, organizations, roles, contexts, and so on (Hansen 2006; Lievrouw 2014; Van Loon 2002), a living milieu (Deuze 2011; Parikka 2010), or as a part of the crisis-technology rhizome (Deleuze and Guattari 1988). But the most suitable conception here seems to be the one suggested by Michel

J. Kotišová, Crisis Reporters, Emotions, and Technology, https://doi.org/10.1007/978-3-030-21428-9_4 
Foucault: technology as a fourfold complex of technologies of production, technologies of sign systems, technologies of power, and technologies of the self (Foucault 1988). In an interview he gave late in life, Foucault insisted that we should not understand technology too narrowly as tools and machines. His words were interpreted by some as shifting the meaning of technology away from materiality toward methods and procedures for governing human beings (Behrent 2013) and by others as encompassing material technologies within practices and means of government (Altamirano 2014; Greene 2012; Hay 2012; Packer and Crofts Wiley 2012; see also Rayner 2001). This study follows the latter interpretation and understands technology as a concept dismantling the traditional bifurcation of nature and society and positioning material artifacts alongside, rather than against, social institutions (Altamirano 2014; Orlikowski 2007).

To be more concrete, James' colleagues' emotional experience at work largely resulted from their emotional labor (Hochschild 1983), so that it was their work in its full extent that shaped their emotional experience:

The work is a filter through which you look at [the crisis]. In the moment, you are not there to get stirred up by what is happening, and the work helps you in it. (Čestmír)

It gives you the reason to go to a place which is unreasonable. (Farrukh)

Their emotional experience was articulated by their position within the hierarchy and corresponding professional tasks; the means of making news, in terms of both processes and material resources; the work with words and images; the feed of disturbing content and the responsibility to tame it and pass it on; and, above all, the work on their selves, stimulating certain emotional reactions and suppressing others, trying to do their job well and to stay healthy at the same time. All these aspects together-all the technologies, or matrices of practical reason telling people how successful professionals should conduct themselves and operate their bodies, souls, and thoughts (Du Gay 1996; Foucault 1988)—constructed the forms of subjectivity that were most appropriate to the social practice in question, in this case the journalistic profession (Du Gay 1996; Foucault 1988,2005 ).

Again, James found it clear as a bell that the emotional experiences, styles, and potential problems related to covering crises were social and 


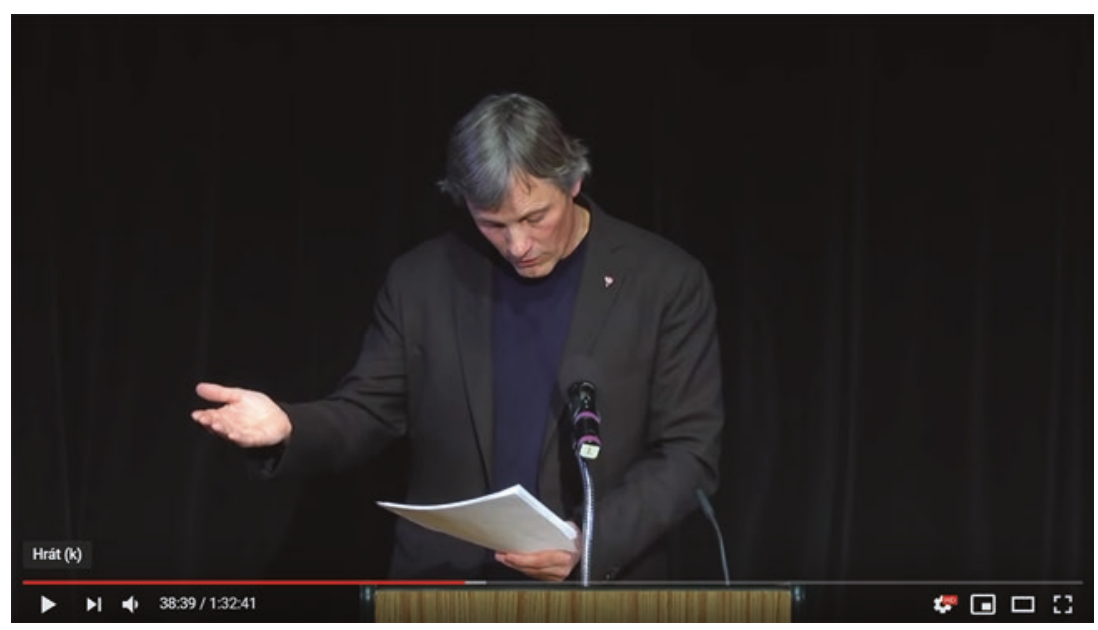

Image 4.1 Albert Camus' historic lecture, "The Human Crisis," performed by actor Viggo Mortensen, New York City, 2016. Source: YouTube, "Albert Camus's 'The Human Crisis' read by Viggo Mortensen, 70 years later"; channel: Columbia Maison Française. Screenshot taken by the author

systemic. They were engendered by the demands of the media-technological environment on one hand, and the crisis contexts on the other.

Camus - or rather Mortensen —was just saying that "nihilism has been replaced by absolute rationalism, and in both cases the results are the same." Did the guys equal the "human crisis" with "absolute rationalism"? James pondered (Image 4.1).

He paused the video for a while. His tranquil rumination about the absolute rationalism started to be disturbed by haunting thoughts of his future report on the catastrophe at San Lorenzo. He still had not planned how he would make the news.

\section{Newsmaking Machine}

\section{Technologies of Production: Practices, Devices, and the Surreal}

Foucault defined technologies of production as one of the matrices of practical reason "which permit us to produce, transform or manipulate things" (Foucault 1988: 18). Regarding the complexity of material/artificial and 
natural/human inherent in Foucault's notion of technology (Altamirano 2014; Orlikowski 2007), technologies of production are both institutionally embedded practices of crisis news production and material artifacts employed in the process. Both facets of the technology of crisis news production were observable in the newsrooms and narrated by the on-the-spot reporters, be they parachutists or correspondents.

In the newsrooms, one could observe the technologies as practices and material technologies in their interplay: the milieu of the $\breve{C} T$ control room, full of "[not-always-] silent co-workers" (Czarniawska 2011: 40), screens, speakers, cables, keyboards, computers, sockets, control panels, partitions, light bulbs, microphones, spotlights, telephones, tilt chairs, computer mice, but mainly screens, screens, and more screens, was a unique stage of human-machine synchronization when an unexpected piece of news came in (and people started to use microphones and telephones more or to watch $C N N$ or $B B C$ on the ubiquitous screens) (Image 4.2).

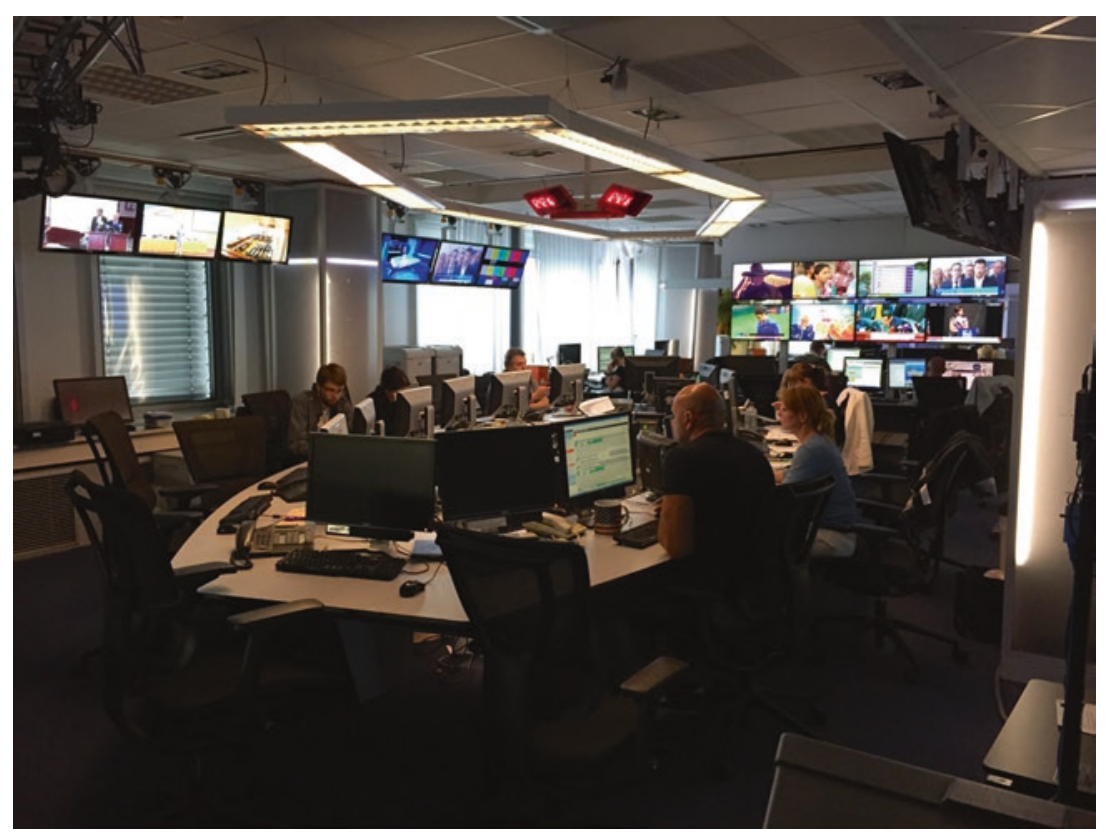

Image 4.2 A control room in Czech Television, Autumn 2015. Picture taken by the author 
Likewise, the narratives often touched upon concrete moments of negotiations, conflicts, and friendships between humans and their cameras, internet connections, batteries, and smartphones.

How did the technologies of production articulate the journalists' emotional experience of crisis?

\section{Same Principles, Different Practices}

The practices of making crisis news were driven by the same principles as making news in peaceful contexts. Why wouldn't they? James thought, and he recalled the often resolute or uncomprehending look of his colleagues after he asked them about any specific practices he should do while reporting on a crisis:

I think they are fundamentally the same. One simply tries to give the most truthful account of what happened. (Matouš)

The reporters referred to the principles of sourcing, verifying, and gatekeeping. Indeed, as Toni G.L.A. Van Der Meer et al. (2016: 13) observe, "[g]atekeeping theory and practices still hold during a crisis; ... Just as in non-crisis times, the findings indicate that journalists remain critical gatekeepers during crises."

"[H] owever, a more nuanced understanding is needed," Van Der Meer et al. (ibid.) continue. Indeed, after the initial denial, it always became clear that making crisis news can be very different from covering non-crisis events. Not surprisingly, there are many differences even between individual crisis events, depending on the extent of their predictability and newness (Nord and Strömbäck 2003; see the section "Typologies of Crisis Moments"). Previous research has illustrated that "[crisis press coverage] does not tone all crises in the same shades" (Ben-Yehuda et al. 2013: 87), which implies that each type of crisis requires certain specific technologies of news production and journalistic practices (e.g. McDonald and Lawrence 2004).

At the same time, however, all the crisis types are substantially challenging. James recalled his thoughts about the dialogue between-and sometimes resonation of-outside-the-media crises and inside-the-media crises (Olsson and Nord 2015; see the section "Inside-the-Media Is Outsidethe-Media Crisis").

First, crisis events often fully fill the news hole (Nord and Strömbäck 2006) or even become a central theme for a relatively long time, so they 
either require immediate organic improvization and fast reorganization of pages/broadcasting (e.g. Emil), or, on the contrary, stir up long, thorough, and time-consuming discussions about accuracy, precision, and ethics (e.g. Čestmír). These contradictory time requirements generate organizational crises ending up in increased pressure felt by individuals.

Second, the reality of gatekeeping practice, in general, follows professional principles more loosely than in non-crisis contexts:

During a crisis, journalists have the tendency to rely mainly on familiar sources such as news agencies and disregard certain other less familiar news sources such as the organization and the public. This journalistic inclination toward certain routine sources might result in a bias in terms of the framing of the event and an imbalanced coverage. (Van Der Meer et al. 2016: 13; see also Falkheimer and Olsson 2015; McDonald and Lawrence 2004)

As a result, sources tend to be mainly English-speaking, such as American news agencies and big international media organizations (Nord and Strömbäck 2003; field work). Again, the sourcing practices in crises depend on the existence of routines and the possibility to make adequate preparations. For example, in terror attacks the journalists tend to use more anonymous sources (Nord and Strömbäck 2003). But using (potentially) anonymous information and alleged eyewitness accounts flooding Twitter, YouTube, and Facebook-in times of crisis, social media hype tends to precede the "traditional" media hype (Pang 2013)—requires careful fact-checking (e.g. Ema, Marie). The pressure becomes even higher.

Third, crises also compel the reporters to perform intensified, often frenetic activity. The process of handling one of the events with the potential to become breaking news looked as follows:

First, someone comes up with the information that something has happened, from Twitter via reliable sources-such as CNN, Reuters, BBC. He/ she informs others sitting in the newsroom about it or calls the editor (in chief). They discuss how to make it, what shots to use first: archive footage? Illustrative footage? Then, an editor makes a call to the on-site reporter and arranges a live entry: when, where and sometimes what to say in case there is little information (depends also on the constraints on site-like the reporter having a broken leg etc.). Alternatively, if there is no foreign correspondent nearby the epicentre of the crisis, the boss "offers" a business trip to a parachutist (i.e. practically assigns her, or rather him). Then, the editor decides how to combine the live entry with other resources. All of this has to be done in a matter of minutes. (Field notes) 
From the perspective of rhythm, such a sudden flurry of action points to time compression in the moment which makes present and turns real the latent crisis continuum, inherently linked to reflexive modernity and risk society (e.g. Adam 2003; see also above). Correspondingly, the speed requirements in newswork and journalism grow (Czarniawska 2011), particularly in breaking moments.

Fourth, consequently, the reporters are supposed to look at the issue/ event from many different angles and to provide as many details as possible (e.g. Sam). The crisis thus has the potential to push the reporters to their limits, to radically change their working hours, and to shift or erase the border between personal and professional time (e.g. Ines, Louis, Josef; cf. Pedelty 1995).

James was by no means an expert on San Lorenzo. As a parachute reporter, he kept moving from topic to topic, with little chance to become an expert in any of them, and, like most other people, he had known very little about the island before he was "offered" to go there. He nervously moved a bit in his seat.

Fifth, in the case of reporting on the spot in hostile environments, reporters were sometimes thrown into physical danger (see the section "Danger and Fear"). This concurs with Høiby and Ottosen's (2015) finding that journalists' professional performance in hostile environments is accompanied by danger, risk, and threat and is corroborated by data and stories provided by the Committee to Protect Journalists and Reporters Without Borders. Nevertheless, Mark Pedelty (1995) persuasively shows that the haze of danger is also a part of the foreign affairs reporters' renegade image, and Brian Creech (2018) shows that the romantic ideal of a reporter marching to war to bring back stories is deeply rooted in European history and tied to colonial expansion. This seeming contradiction of precarity, constituted by the growing threat of bodily harm, and promise of fame and success, not only stems from the increasingly individualized risk (Beck 1992) that is accepted for the sake of one's own reputation and that of one's media organization but also reflects the distinction between international correspondents/parachutists and local journalists. The risks facing journalists are vast, and unequally distributed among staff international journalists, freelancers from Europe and the US, and local journalists, stringers, and fixers. While locals living and reporting in hostile environments, together with their families, are much more likely to be exposed to danger and usually face the most severe threats of violence (Creech 2018; Høiby and Ottosen 2015), the privileged international correspondents- 
that is, James' colleagues and Pedelty's interviewees - rarely put their feet on "battlefields." Instead, they stay in relatively safe capital cities, the headquarters of international organizations, residences of local officials, press conferences, hotels, and restaurants (Pedelty 1995). Yet, at least Josef, Sam, Anthony, Jesse, Čestmír, Vítek, Nicolas, and Tomáš had gone through life-threatening situations.

The technologies of making crisis news also impose increased and specific risks on women: most of the threats to women consist in sexual harassment, verbal threats, abduction, rape, and forced "marriage." "Kidnapping, rape and violence is of regular concern for women journalists at work" (Høiby and Ottosen 2015: 66). Women face these dangers especially when covering local conflicts.

James was wondering why he had not heard anything about this from his female colleagues. If they complained, the reason was rather their invisibility (Ines).

As has been suggested in the section "Danger and Fear," due to the danger, conflict zone news sometimes relied on only one side of the conflict:

Rarely can you show both sides in one report. Almost never. Because there is simply a front line between them, which is very hard to cross. (Čestmír)

According to Čestmír, and also some media scholars, this often results in "less professional" news (e.g. Olsson and Nord 2015). Alternatively, a reporter can devote a large amount of time and energy to travel to the other side of the conflict, as Sven did in Kosovo:

There were really ... snipers etcetera, so it was really dangerous. So back in Brussels, I felt I had the Kosovo side, the Kosovo-Albanian side of the story. And I was a bit in a non-balanced situation. ... So after a couple of weeks, I travelled to Serbia to get the story from the Serbian-Macedonian side. And then, at the end, I felt, ok, I am in balance now.

As Nicolas, Sven, Jesse, Čestmír, and some others said, it is important in dangerous conditions for the reporters and all members of the team to have formal autonomy-the right to assess the risks on the spot and to decide what level of danger they are willing to accept. But in reality, the reporters themselves are on the top of the hierarchy, followed by editorsin-chief, photographers, sound engineers, and fixers, for whom the reporters feel responsible. This further intensifies the stress (Jesse, Gloria). 
Finally, sixth, in crises, James' colleagues were also faced with and constrained by various legal restrictions (e.g. Sam or Tomáš). The saying that "the first casualty of war is truth" was true, due to legal and official restrictions under crisis circumstances, whether well-founded or introduced under pretense of security measures, and because reporters may be greatly distanced from events, first-hand witnesses, and participants (Pedelty 1995). Alternatively, they may be offered restricted access. This was the case of some Belgian and Czech reporters who, after returning from Syria, were harshly criticized by other journalists for going there "at Assad's invitation" and echoing the official, governmental point of view and conveying Assad's politics/justifications. A few of James' colleagues believed that the legitimacy of covering conflict zones in this way-say, interviewing Assad-“depends on the questions." (Sven, Ernest)

The specificity of the practical technologies for making crisis news was often reflected in the visible innovations on the pages or in broadcasting, as proposed at a meeting during the police interventions in Brussels after the Paris terrorist attacks in November 2015:

Martin suggests, due to the extraordinariness of the affairs, to "disrupt" the format of UK (an evening programme): "...to enrich it with one more presenter, so that the people see that something strange, unusual is going on." (Field notes, $\check{C} T$ )

Through "disruption," "enrichment," and other subtle technologies of production (representation), the risk of global terrorism became visualized, signified - and valorized (Van Loon 2002).

James took a banknote out of his pocket and passed it to the flight attendant. Its value, James thought, exceeded the value of his nauseating snack by far, but at least The Mo paid for it-regardless of its chronic decline in readership.

Despite the obvious economically rational dimension of the adjustments Martin pushed for, James never noticed any difference between public service and commercial media in technologies of crisis news production. As Nord and Strömbäck write,

it is hard to generalize from structural factors ... neither media type (TV vs. newspaper) nor media category (tabloid vs. broad-sheet papers) or ownership (private vs. public service) can explain these patterns [of making crisis news]. (Nord and Strömbäck 2003: 67) 
In contrast, according to James' colleagues, there certainly was a difference between Czech and Belgian media. Czech journalists tended to "look to the West" (Čestmír) instead of following Czech journalistic traditions, because in Czechia "it is not going in the right direction." The difference was particularly striking when James compared Lotte's (Belgian public service TV reporter) and Marek's (Czech public service TV reporter) narratives of September 11. Lotte said she had immediately started to work "on automatic pilot," while Marek recalled that "the whole newsroom had been totally appalled, watching CNN for 25 minutes before someone finally got the idea to go and prepare a special broadcast." Since then, the $\check{C} T$ journalists have learned to react much more nimbly (see the field notes above on the changing newswork rhythm under crisis conditions). According to Čestmír and Vítek, from the escalation of the RussianUkrainian conflict on, $\check{C} T$ has even approximated its Western and Westernlike models.

Wishful thinking, ever-skeptical James thought, and he remembered that Sophie Schlesinger was just sitting right in front of him. He pricked up his ears and heard she was just scribbling something down. No doubt she was getting ready for the job she had at San Lorenzo. And so James too finally got down to sketching his future report. Possible types of sources to get, social media to use, structure to keep, potential conflicts to highlight. He only hoped to be able to work fast enough and to have a steady connection with The Mo.

To sum up, all six answers to the question "what is specific about technologies of crisis news production" intersect in one word: pressureheightened pressure on accuracy, principles, speed, precision; investment of one's personal time; placing oneself at risk. These were all various sources of precarity.

It needs to be stressed again that the journalists' and reporters' precarity is unequally distributed among staff reporters, freelancers, and local journalists who call the crisis zone their home and whose labor remains largely invisible to European audience. As Brian Creech (2018) argues, the economic conditions and cultural logic surrounding crisis (mainly conflict) journalism-the exploitative relations between media workers and organizations together with the myth of an independent, brave truth-seeker-normalize journalists' increasing precarity and make it acceptable. Any intervention thus requires engaging critically with both the economic logic and the normative ideals surrounding crisis reporting. 


\section{Mediators Matter}

The practices of crisis news production were entangled with things. The ways in which individual devices used for crisis reporting can influencenot only determine, but also "authorize, allow, afford, encourage, permit, suggest, influence, block, render possible, forbid, and so on" (Latour 2005: 72)—journalists' emotional experience, were particularly clear in parachute reporters' and correspondents' narratives. Artifacts like cameras, pencils and notebooks, recorders, smartphones, and transmission vehicles all intervened, in a deeply ambiguous way, in how their users lived out the process of covering a crisis. As such, the artifacts were mediators rather than intermediaries. Whereas an intermediary "transports meaning or force without transformation ... [m] ediators transform, translate, distort, and modify the meaning or the elements they are supposed to carry" (Latour 2005: 39). The material technologies of crisis news production did not merely passively capture and convey words and images, but actively influenced the journalists' experience.

Most typically, James' colleagues claimed that looking at graphic scenes such as mass graves through the viewfinders of cameras and camcorders made a significant difference:

there were more than three hundred bodies. Dead people. And the smell was really strong. (...) I remember putting the camera in front of me because I couldn't watch the faces of the people directly. People who were shot in their head, or whatever. And when I remember that, I don't remember it as a real situation. It's like a movie. Because ... I couldn't watch it directly. (Ines)

the picture is something that does not really exist. (...) So it's a way of having distance from what's happening in front of you. (Nicolas)

The material technology of production works as a means of distancing the media workers from their subjects and reality (cf. Richards and Rees 2011; Sontag 1977); as a buffer. The more technology the reporter uses, the more shielded she is; as Farrukh noted, "Camera and a press card are acts of power." Thus, in the case of television production, the complex technological equipment is "mentally more comfortable" (Vítek) because its presence implies that the reporter must follow simple steps.

However, the view that technological devices can help a reporter to stay detached from the crisis and reduce the mental strain was opposed by others, who stressed the fact that technology also necessarily brings the 
reporter closer. Anthony, living in Peshawar and using "only" a voice recorder, did not begrudge his photo-colleagues the need to march in the middle of angry crowd. Matouš, who worked as a reporter and editor at $\check{C} T$, compared his technologically demanding work with his previous experience at a news agency where he was "merely" writing:

[When I was working] for the [news agency], it enabled me-since I was writing - to often be rather like a fly on the wall, a non-participant observer of the situation. So the camera. ... Firstly, what one has not shot, one does not have at all. So the very fact of what television is, and the camera, forces one to be close to the situations, to enter them. And this changes everything.

The material technology of production allows much more than ten years ago and needs to be utilized; as Vítek evaluated based on his 17-year television career, "I can really see that the demands on the people grow terribly, because the technology simply can make it." New and social media are stressful for other reasons:

You have satellite phones that we did not have some time ago, you have the possibility with the small devices to do the editing and send it quite immediately, so you are able to operate ad hoc, faster, and on the spot, and continue with your work without having to go out. (...) It gives you ... emotionally, I think it's like everything with social media now, now it's also ... It's more intense. Because it's immediate. (...) So I think it absorbs you more. I think it's affecting you more. Especially since the last. ... The Arab revolutions, and now Syria, after that, because we are ... Since then, we've changed our way of working. It became different. Before, you made a news story. Which is intense. But since then, we make news stories, we have to produce for online, for Facebook, for all these things, which is a duty that follows from your work, and we have to do it immediately. (Sam)

In Sam's opinion, the ever-progressing material technology, its opportunities and power, and related changing newsroom routines, working conditions, and the power of (new) media logic have together had a rather negative effect on the ability of reporters to maintain mental and emotional detachment.

In sum, the technological affordances, "opportunities for or invitation to actions that things present to actors" (Lievrouw 2014: 48) bring about very diverse effects on reporters' emotional experience. They can allow a reporter to take footage and to mediate her authentic experience of the on-site presence (Andén-Papadopoulos and Pantti 2013); keep her 
distant; make her cover as much as possible; allow/push her to approach the crisis scene from unprecedentedly close range, and thus place her into its focal point. In doing this, the material technologies of production and the practical/processual technologies of production are always embedded in each other, as succinctly expressed by Čestmír:

For me the technology is not a physical filter. It is a psychological filter-in the sense that my mission there is different. (Čestmír)

The technology helped Čestmír to overcome stress by delimiting his organizational identity (Weick 1995). In this context, Wanda J. Orlikowski (2007: 1437) writes of the constitutive entanglement of the social and the material: "materiality is integral to organizing, positing that the social and the material are constitutively entangled in everyday life ... the social and the material are considered to be inextricably related." Čestmír thus happened to be constitutively entangled with his media organization and the material technology of crisis news production.

\section{The Sense of Surreal}

James saw and heard several moments when the media materialtechnological complex of processual and material technologies of production totally seized a journalist's or James' own sensory field and made a crack in their sense of ontological security (Giddens 1991). These moments that James' colleagues described as "very strange" or "surreal" were always connected to the "abnormal" experience with a distant crisis and especially with close crises. As such, they were most explicit in the narratives of Belgian journalists who had reported on the terror attacks in Brussels (see the section "Belgium, Czechia, and the Closeness of a Crisis"):

You're in a strange situation that you have, you see war correspondents- -literally, I've seen war correspondents in my city. (Laughs.) Which is very strange! And Christiane Amanpour flying over to Brussels to interview the prime minister, and ... We used to see it as just distant. ... It's not only in Belgium. It's not a globalization of risks, it's a sort of everywhereness [of risks]. (Jacob)

Jacob perceived the uncanny omnipresence of the terror threat, reflected upon the changing distribution of risks, and hinted at the significance of their discursive construction by the global media (see Beck 1992; Van Loon 2002). 
But the funny feeling was not limited to those who reported a crisis close to home. Rather, the feeling was connected to the contrast mentioned in the section "Identified": a more general and widespread sense of inconsistency, rupture, and difference between the ordinary everyday life of a contemporary middle-class, typically white, university-educated European, and the everyday living conditions in a conflict/ disaster/war zone:

in Kosovo or later, in Congo, for example, it's also very surreal. Of course it is. If you are standing on this side of the hill, and you know that you can't climb the hill, because otherwise they will shoot at you, it's. ... We are people from the peace continent. We never really experienced war ourselves. (Sven)

I must be very disconnected from this world. Yeah. Because you are so long in that world, in another kind of world. I mean, you have so many roles. I cannot explain it. (Sam)

Likewise, Anthony, when he touched down in a crisis region, felt "as if [he] landed at another planet."

The odd feeling was thus related to the very essence of the risk society/technological culture (Beck 1992; Van Loon 2002): not only the dispersion, both physical and mediated, of uncertainties and suffering, emerging as an unintended consequence of ever-advancing technological knowledge, but also the connectedness (yet stark contrast) of different parts of the world. The technological knowledge needs to be stressed, since the core of the funny feelings, the merging of worlds, was largely shaped by new media affordances (Lievrouw 2014). Charlie Beckett and Mark Deuze (2016) have identified a kind of surreal, magical, even wonderful experience among audiences following from the ubiquitous and networked character of news. If this is the case for audiences, the journalists simply hold a much more intense position in the middle of the transitions:

When I am there, I am here, because of [social networking sites], and when I am here, I am there. So I am always ... there, basically. ... Last year, two of my translators, one from Gaza and one from Egypt, had to flee because of the risk of torture. So now they are in Belgium. So now they are here. So that world has come here. (Sam) 
Only a few reporters reflected on the relative newness of the experience as explicitly as Sam did in the last two quotations. Many, however, incorporated the gap between the two worlds and the sense of discrepancy into their kynical coping strategies, such as Richard during a meeting at $L N$ and Čestmír in the $\breve{C} T$ control room:

Tobiás proposes to write an article about so-called "children of the Islamic state": "Sixty children of the jihadists from Europe have already been born, and the Daesh doesn't know what to do with these children." Richard: "Ah, whether to put them in kindergarten, or a day nursery, right?" We all burst out in laughter. (Field notes)

A conversation between Marie and Čestmír about some footage released by Daesh. "What crazy shots, there. So dreadful, how they burn the people to death in the cages," Marie says. "Fucking beasts. Now, they have pissed off the Chinese by executing their man," replies Čestmír. "Murdered, not executed," Marie corrects him. Čestmír gives a smile: "Thank you. Thank you for putting me in my place, instead of me myself," Čestmír replies, and continues: "Norway will get pissed too, and the Daesh will never get Nobel Peace Prize." (Field notes)

A few times, James felt the magic himself. It was when he saw a camel at the $\check{C} T$ headquarters, lazily walking into the main building (managers' entrance). Or when he came, through a heavy yet hardly noticeable garage-like door in the center of Liège, into a beautiful, expensive, decadent art deco residence of a former journalist and started to listen to stories in which the journalist was both the main character and the narrator. Or when he was sitting with Sven in Le Cirio, an art nouveau brasserie next to the Bourse in Brussels.

Sven was just speaking about 1989:

I mean, you were part of another world. And I think that was also. ... That was also quite a difficult period to write about. And now we are talking about it, but for example. ... That man! (Points out the window.) He was too fast, actually, but it's a former colleague. An Eastern Europe expert. (Laughs.)

The man flashed past the door of Le Cirio.

Actually, that's interesting. It's a pity that he doesn't come in, but ... Because he studied literature, and he was interested in Kafka. So he went to Prague and there, I think, he had a lot of contacts with the group around Václav 
Havel. And so ... And the Charta people. And then ... he has been followed by the Czech security services in Brussels. (Sven)

James was once again reminded of the absurdness of the inertial past of the former Eastern Bloc, of the volatility of the distribution of risks, and of their iceberg-like invisibility (Beck 1992).

He heard the robotic flight attendant's voice emanating from speakers, and took off his headphones. "... and the number is constantly growing," she just said, most probably informing the passengers of the latest developments at San Lorenzo. The audience reacted by deafening silence. The voice was waiting for questions. No questions were coming. Was it anxiety or apathy (Van Loon 2002)? Probably both, James thought. It took less than half of a second, and the same flight attendant suddenly emerged from behind, imperceptibly singing a joyful tune with a hint of melancholy and striding toward the nose. Someone cut through the silence with a question. James rather aimed his attention back to the technologies.

\section{Technologies of Sign Systems: Output Emotions}

Foucault defined technologies of sign systems as a matrix of practical reason "which permit us to use signs, meanings, symbols, or signification" (Foucault 1988: 18). How do the ways of using words, images, sounds, mixed signs, and symbols relate to journalists' emotional experience of crisis?

James reached for the issue of Le Soir he kept carrying in his bag. It was the issue from 23 March 2016, and he thought it was adequately emotional. Which meant, a lot.

James perused the black title page, the strong headline "Tenir bon," the hopeful image. A person wrapped up in Belgian flag with a non-white child, both drawing, with chalks in their hands and watched by a grieving semi-circle, one of the supportive signs and writings of condolence that, after the attacks, colored all Belgian cities.

Then, he cast his eyes at the pleading editorial written by Christophe Berti (Berti 2016). It began with "D'abord, l'émotion," and contained many emotion words; the article was even structured by different emotional phases: emotional shock, fear, questions, and sentiment. ${ }^{1}$ Reading the article, James felt the vivid memories.

\footnotetext{
${ }^{1}$ While "emotion" referred to shock and solidarity, by sentiment, the author meant strictness and primarily hatred-which needs to be fought.
} 
Likewise, what follows focuses on exploring the technologies of sign systems within crisis reporting and their entanglement with emotions through focusing on the reporters' notions of the role and place of emotions in crisis news. The perceived ideal and real place of emotions in crisis news-in Nico Carpentier's and Marit Trioen's words, the position of emotion within "objectivity-as-a-norm" and "objectivity-as-a-practice" (Carpentier and Trioen 2010), can reveal motives, desired results, and conscious parts of journalists' emotional labor (Hochschild 1983), because the ideals/norms and practices co-determine (and are co-determined by) emotional engagement, identification, actorship, and the criticized "activism." More precisely, emotional engagement and identification can easily result in the open or covert taking of an active role within the story (see the section "Moral Dilemmas and Guilt") not only by helping people on the spot but also by subtly, unobtrusively making emotional news that can work as an appeal (Boltanski 1999). Furthermore, the reporters' ideals and ideas about emotions "on the output," that is, the practical reason permitting them (or not) to make emotions (in)visible in the news, are plugged into the other technologies. The images, sounds, words, hyperlinks, and so on that the journalists use largely depend on media affordances and journalistic routines (technologies of production); they result from the codified and non-codified regulations of journalists' practices, such as ethical codes, organizational guidelines, and shared professional ideology (technologies of power); they follow from the journalists' ability to discipline their emotions (technologies of the self).

In this context, Karin Wahl-Jorgensen's analysis of Pulitzer Prizewinning stories stirs up further sub-questions. Wahl-Jorgensen speaks about a "strategic ritual of emotionality" and suggests that "there is an institutionalized and systematic practice of journalists narrating and infusing their reporting with emotion" (Wahl-Jorgensen 2013: 130). The ritual operates alongside the analogous strategic ritual of objectivity. As a result, emotionality is profoundly constitutive of journalistic narratives (Peters 2011; Wahl-Jorgensen 2013). In particular, crisis news are designed in a subjectively impacted and emotionally driven way (Altheide 2006; Falkheimer and Olsson 2015; Lull 2007; Van Der Meer et al. 2016). Nevertheless, rather than expressing their own emotions, WahlJorgensen suggests that journalists "outsource," police, and discipline others' emotional expression. The question remains, however, whether the emotions are really "outsourced." Is it only the emotion of a talking head, a victim, or the victim's relatives that colorizes the news? Is it rather 
reporters' own emotions? Or is it some kind of diffused feeling that is sublimated only thanks to the narrator (e.g. Culler 1997)?

\section{"The Right Dose" of Emotion}

The reporters' ideas of the role of emotions in the process and outcomes of newsmaking - that to a large extent expressed the kind of "objectivityas-a-norm" (Carpentier and Trioen 2010) they respected-were considerably varied. On a scale with two ends, the "reports-should-be-objective" end, and the "emotions-is-one-of-the-facts" end, James was able to identify three ideal-typical positions of his colleagues: Positivists, Measurers, and Franks. ${ }^{2}$

The first group, Positivists, was composed of very few people. For Positivists-usually, but not exclusively, young Czech and Belgian reporters with journalistic education (i.e. possibly with fresh awareness of theoretically and traditionally conceived journalistic professionalism)—news should be completely free from subjective emotions, neutral, and objective. A journalist should keep emotional distance in order to either transmit pure information or retain a critical stance toward all sides of the conflict:

it is of course emotionally difficult in a way, and ... Eee ... But ... (Silence) I think I succeeded, in this particular situation like in Tunisia, in keeping the distance from it. I feel that way. I was just describing reality. (Silence) And ... It really is difficult. Simply because you are thinking. (...) I must be objective and pass the reality forward. (Kryštof)

We are trying to be very neutral, like water. (Carl)

for the news, I really say what I see, without any emotional timbre. (...) It shouldn't be in the news. (Tomáš)

The Positivists thus revived and strengthened (Wiik 2015) the traditional positivist-realist version of objectivity-as-a-norm, valuing detachment, complete neutrality, and impartiality (Carpentier and Trioen 2010; Schudson 2001).

\footnotetext{
${ }^{2}$ The three groups were contingent in the terms of people-mainly because some journalists did not care about the inner consistency of their normative notions and opinions-but delimited regarding the typical view of the role and place of emotions in crisis news.
} 
This position was considered obsolete by the Measurers, a much bigger group. For Measurers - typically more experienced, and thus more practically professionalized-emotions do have room in the news and reports, because their "right dose" (Sven) or "a layer" (Nicolas, Jesse) adds to the author's credibility and to the "humaneness" of reporting (Lotte):

The emotions must be there. One can't avoid them, because it's an intellectual job, you work with words, with thoughts. ... but you should be able to control it. (Astrid)

I think the work is better if you let in some kind of emotion. Not all of it. You cannot be swept away completely by your emotion, because then you won't be accurate any more either. (Lotte)

With the right dose of emotion, you add to your credibility. I mean, if it's too much, if you put yourself in the foreground and you talk only about your own emotions while the emotions and the problems of the people you're writing about are much bigger, it's a bit pathetic to me. If you're just trying to be a machine, follow the reader, it's also very strange. (Sven)

Sven directly links the control of one's emotion with avoiding egocentric news, news focused on the journalists themselves, news that do not express the different significance of European journalist's emotion and the Other's emotion accurately, that is, with avoiding the unethical journalistic performance that was so harshly criticized by some other reporters (see the next section).

This second position best concurs with Wahl-Jorgensen's notion of policing and disciplining emotions (Wahl-Jorgensen 2013); in contradiction to her findings, however, the emotions allegedly belong to the very reporters who invoke, suppress, and manage their emotions in line with the requirements of their profession (Hochschild 1983; Illouz 2007).

The third ideal-typical view - that of Franks - was also rather widespread and appeared in many discussions. Franks insisted that emotions "should be there" because they are "one of the facts" (Lotte). Many of James' colleagues perceived their own emotional experience, the emotions of their talking heads and the emotionality of the stories being covered a significant part of reality; their personal value added; the very reason for reporting on the spot; or even, as Josef said, the "raison d'être of the existence of television": 
I think it's wrong not to include the emotions. It's stupid. Because that's what you can do if you make a report from Prague, based on agency materials. Sure. But the virtue ... why the report from the place is better than from Prague, it's not only that you have a stand-up there by which you are proving the medium is there, but just because you experience it. And because you are not a perfect robot but a mere human, you are able to include the drive. (Vítek)

[A child trying to find her father's body in the rubble] is a thing that is so very loaded with emotions that not to describe the emotional dimension would mean simply to flatten it. To flatten it brutally, and basically to distort reality to the extent that it won't resemble what was really going on there. (Čestmír)

The scale in general tallies with Patrick Plaisance's and Elisabeth Skewes' finding that journalists are deeply ambivalent toward the so-called interpretive - that is, non-informative-function of the press. However, Plaisance's and Skewes' analysis shows that journalists perceive a negative correlation between the analytical, interpretive, and explanatory role of the media on one hand and their notion of responsibility on the other (Plaisance and Skewes 2003). By comparison, while few James' colleagues saw emotionality in crisis news as a sign of failure or bad taste, most of them did not consider impressions, emotions, and openly value-driven interpretation as a threat to factuality and professional responsibility.

It is necessary to stress again, however, that all the discursively constructed professional positions are a testament to "objectivity-as-a-norm" (Carpentier and Trioen 2010)-manifesting itself in "I must," "we are trying to," "it shouldn't be," "the right dose," "the work is better," "it's wrong," and the like-professional principles and values, rather than actual practice. One can only assume how these norms are enacted.

Nevertheless, the diversity of positions reflects a certain variety within journalists' professional ideology, a collection of shared but continuously challenged strategies and values guiding the construction of their expertise and authority (Andén-Papadopoulos and Pantti 2013: 962). While the traditional version of this ideology appreciates objectivity understood as detachment, impartiality, fairness, and professional distance, alternative and more recent approaches have been advocating for the acknowledgment of reporters' emotions as a legitimate part of their work (e.g. Pauly 2014; see the section "Professional Ideology and Its Critique"). 


\section{"No Torn Children's Life Jackets": Taste, Organization, and Moral}

\section{Commitment}

All of the reporters were well aware of the danger of overdoing the articulation of emotionality - be it their own or the victims'/witnesses' emotions-and building a "melodramatic" story. Making a report about a shipwrecked boat full of migrants, about a bleak camp along the Balkan route, or about the victims of the Bataclan shooting means a constant search for the border between an "awkward," "emotionally blackmailing," "caricature-like," "cheesy," "syrupy" testimony, and a transmission of a serious, information-based, and accurate account of what happened (including the emotional level). For the primary goal of anything that appeared in the reports-including emotions-is to inform and not to take a standpoint:

You have to control your emotions and use them only if they explain what happens. (Anthony)

You must find the level where the emotion, whether positive or negative, strengthens the information that you hand over. But you don't do it systematically, because of the emotion, because of picking at it. (...) We are of course always trying to show [the news] through a story, through a person, instead of making it a cold list of facts, but not to rummage in torn children's life jackets. (Ester)

So, although some reporters even explicitly stated that "objectivity doesn't exist" (Sven, who, as a student, wrote a thesis on New Journalism) or that "neutrality is a joke" (Nicolas, who gave university lectures on narrative journalism), they knew they could-and should-be "factual." Factuality meant a different thing than neutrality and objectivity. "Never mess up with the facts," Sam once warned James. And by "never mess up with the facts," he meant not to distort and omit any proved information. He did not mean "be cold."

James was determined to stick to the facts. Any other strategy would be strongly condemned in The Mo. The Mo enjoyed the image of a quality paper, and James wanted to contribute to that impression-shaping also his own professional image - as much as possible.

Indeed, some of the journalists saw it as a distinguishing feature of "their" media organization be it one of the public service televisions or 
one of the serious newspapers - that its authors and reporters work carefully with sound background, word choice (e.g. they prefer using no comments to impassioned, "mournful" adjectives) or overly explicit footage that unnecessarily exploits viewers' and readers' emotions. They felt the responsibility to stick to the character of their medium: "we really don't want to be cheap television," Lotte summed up. Freelancers seemingly had more freedom, yet they needed to keep their fingers on the pulse and adhere to the style of the media they wanted to publish with anyways.

James, planning out the report more and more hurriedly, gave some thought to possible pictures. Of course he could take a photograph full of frozen corpses in unnatural positions; one of those he saw earlier on Twitter. Such a picture would certainly attract attention. But considering the image of The Mo and his own taste, he knew he would rather go for something discreetly powerful. Like a frozen, empty city (Image 4.3).

This strategy had a moral dimension. Some individuals and media organizations that James had encountered tried to avoid a plain spectacle of

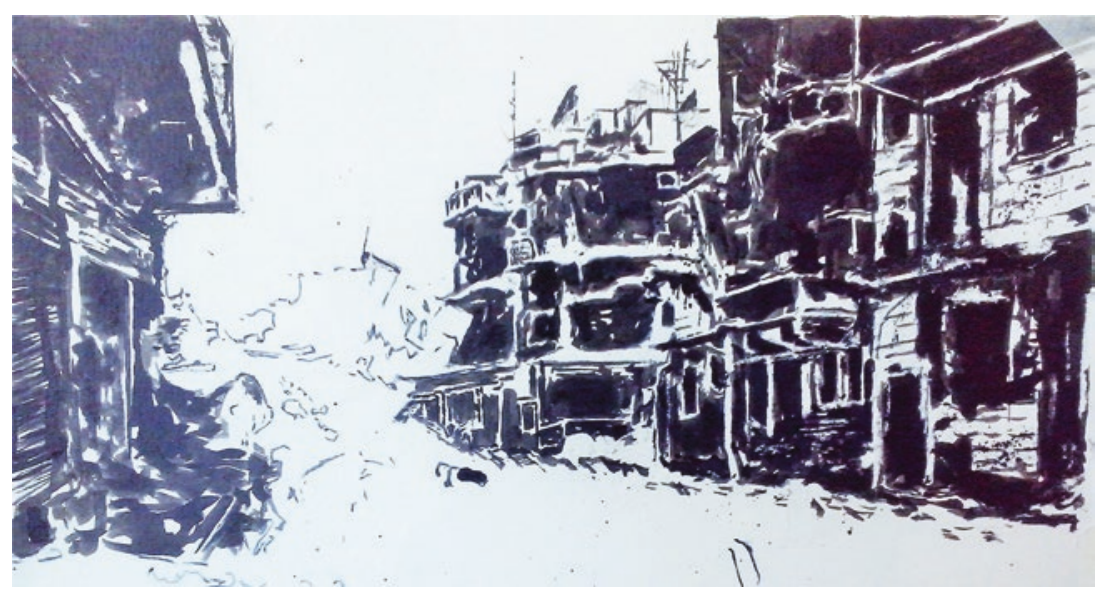

Image 4.3 A frozen city. Drawing by Peter Van Goethem, 2017. Courtesy of the artist 
suffering that would further increase compassion fatigue in audiences (Moeller 1999). On the other hand, in order to respond to the humane commitment, the journalists had to commit themselves through speech acts, by adopting a stance, by reporting both what they had seen and how it personally affected and involved them. As Luc Boltanski suggests, a morally acceptable formula for the communication of suffering involves the use of evaluative and emotive terms:

in order to respect a rule of common humanity, the spectator of suffering cannot adopt the stance of a subject describing an object and speaking of what he has seen as a simple reporter. He cannot describe the execution of condemned persons, or the bodies of dead children during a famine, with the same kind of precision and detachment one would use to speak of a system of economic regulation, a policy of regionalisation, or a plan for a road network. (Boltanski 1999: 43)

Describing their internal states thus had three important functions: first, it could help the journalists to reduce tension stemming from the cognitive and emotive dissonance (Festinger 1957; Hochschild 1983) and therefore was psychologically helpful. Indeed, Giuseppe-although an employee-said that he did not need any coping mechanism because he had complete freedom from his bosses, and he could write what he found important in a way he found suitable. His freedom shaped his overall experience. Second, explaining their emotional states could help the journalists balance aperspectival objectivism (the position of Positivists) and moral involvement (the position of Activists; see Boltanski 1999: 41). Including some level of emotions was thus both psychologically helpful and necessary from the moral point of view. Third, and importantly, as Beckett and Deuze (2016) point out, including reporters' emotionality can be a step toward more effective journalism, as authentic emotion linked to news reporting helps journalists connect with communities and thus to foster objectivity and trustworthiness. Wahl-Jorgensen agrees: "rather than necessarily undermining the rationality of the public sphere, emotional expression may be a vital positive force in enabling new forms of engagement and identification among audience members" (Wahl-Jorgensen 2016, p. 2).

However, it needs to be stressed again that James, like many of his fellow reporters, hated placing the reporter in the center of the narrative. For example, Farrukh criticized the photographer Linsey Addario who was 
outraged by-and publicly spoke a lot about-being forced, while pregnant, to repeatedly go through an $\mathrm{x}$-ray machine when she was covering Gaza:

And she had nothing to say about the fact that every day, every month thousands of Palestinian women have suffered the humility. ... Many have had to give birth at checkpoint. Many have died giving birth at checkpoint.

According to Farrukh, her suffering was relatively insignificant relative to suffering of Palestinian women, pregnant or not, yet she behaved in an egocentric way. Similarly, Bob and Anthony thought that journalists should not be TV stars: "Journalists are not the victims, we should not be the protagonists, the heroes." (Bob)

Regrettably, the trend, according to the critics, seemed to be putting oneself in first place and (ab)using the tragedies of one's sources by giving them the status of mere scenery within which the reporters' story unfolds. Nikki Usher (2019: 141) has even assessed the increasingly tiresome and growing "obsession journalists have with journalism as its own story" as one of the reasons why journalists are the worst enemies of journalism today.

Thus, James did not fool himself into believing that all of his colleagues used emotional words in crisis news to fulfill their moral commitment or as a defense mechanism. Emotion in crisis reporting could be a result of pure economic calculation, notions of professionalism, or aesthetic sense. Most probably, it was a result of everything together.

Yet, who is the bearer of emotions in the news, still seemed unclear. It could be partly the journalists themselves, partly their subjects and interviewees, partly the speakers, and partly the narrator. As Sam said, "My sadness from seeing things guides me to witnesses who translate this. Because it's their sadness." Sam's words suggest that the talking heads, victims, victims' relatives-all the subjects and interviewees-are the reporters' mouthpieces, "spoken by" the reporters' genuine emotions and selected more or less intentionally according to the conformity of their emotions with those of the reporter exercising her gatekeeping role. In this sense, emotions in the news were outsourced indeed (Wahl-Jorgensen 2013) but predetermined by the journalist's specific demand. Steen Steensen (2017) solves the question of whose emotions appear in the news by distinguishing source subjectivity, that is, witnesses', victims', and other talking heads' subjectivity which personalizes and exemplifies the story, and byline subjectivity, referring to a situation in which it is the author herself who imbues the story with her subjectivity. 
Alternatively, the emotion can be diffused throughout the different identities connected to the story, rather than expressed by a concrete person; it can exist solely through the text. In such an instance, emotion ceases to be emotion and becomes affect. As Brian Massumi (1995) writes, affect is a virtual and synaesthetic (i.e. not ownable by a concrete person) perspective anchored in and embodied by actually existing things (e.g. a text). Emotion, on the contrary, refers to "a subjective content, the sociolinguistic fixing of the quality of an experience which is from that point onward defined as personal" (Massumi 1995: 88). Thus, any feeling that circulated in the news and was not assigned to the physical author or one of the characters in the story was positioned in between affect and emotion: socio-linguistically fixed but not ownable. Captured in a piece of language but still dispersed.

Be that as it may, the perceived ideal of "output" emotions and affects directly shaped the way the reporters worked with their emotions; in turn, the emotional labor-driven by professional ideals and other criteria of success - influenced the actual, real form of emotions in the news.

For a moment, James put on his headphones again. Viggo Mortensen, Camus' mouthpiece, was just speaking about the most obvious symptoms of the "human crisis." "The first symptom is the rise of terror. A consequence of the perversion of values through which human beings and historical forces are judged not in terms of their dignity, but in terms of their success. The modern crisis is inevitable. Because no one in the West can be sure about their immediate future. And all live with the more or less defined view that they will be crushed a bit, one way or another, by history." James felt tiny and meaningless, and the very next thoughts were about to make it even worse.

\section{Technologies of Power: Discipline and Publish}

For there was the question concerning technologies of power. Foucault defined technologies of power as a matrix of practical reason "which determine[s] the conduct of individuals and submit[s] them to certain ends or domination, an objectivizing of the subject" (Foucault 1988: 18). Technologies of power is a more general category within Foucault's theory, given the scope of effort he dedicated to the conceptualization of power as a ubiquitous, active, and productive practice, permeating all subjects, coming from below and within, rather than encompassing subjects (Deleuze 1996; Foucault 1978). 
Like other technologies, the technologies of power permeated many aspects of journalists' emotional experience of crisis and were connected to the other technologies. The reporters' ways of experiencing and handling emotions resulted from two broad areas of technologies of power. First, from journalistic professional ideology: the acquired theoretical notions of professionalism on one hand, and journalistic codes and other regulations of correct journalistic action on the other. Second, from the journalists' individual positions within the organizational hierarchies (as suggested by the very distinction between Positivists - typically rookies - and the Measurers and the Franks), that is, from the conduct of individuals within the media organizations, including various guidelines or to-do lists.

\section{Professional Ideology and Its Critique}

As has been outlined at the beginning of the book (in the section "Objections to Objectivity: Emotionality and Professionalism"), the traditional version of journalists' professional ideology, that is, a system of beliefs characteristic of the particular group, a collection of shared but continuously challenged strategies and values guiding the construction of their expertise and authority (Andén-Papadopoulos and Pantti 2013: 962; Deuze 2005: 445), includes a commitment to objectivity (understood as detachment, impartiality, fairness, or professional distance). Together with other norms and values, such as autonomy and public service, objectivity represents the core normative and ethical aspect of professionalism (Andén-Papadopoulos and Pantti 2013); some scholars even argue that the objectivity norm is central to the constitution of the journalistic field and works as a privileged signifier of "good journalism" (Carpentier and Trioen 2010; Vos 2011). Professionalism and objectivity understood in these terms, however, mean staying cool and unemotional (Schudson 2001).

In the shaping of professional ideology, the Foucauldian entanglement of power and knowledge (Foucault 1978) is clearly visible, as the professional ideology is reproduced by academic knowledge on journalism and media. Many studies are explicitly normative, promoting the traditional positivist version of objectivity. For example, Nord and Strömbäck evaluate Swedish coverage of the war in Afghanistan and September 11 as problematic due to certain media strategies specific for crisis reporting:

the line between fact and fiction sometimes has become increasingly hard to discern, due to the frequent use of speculations, the blending of straight reporting and commentary, and the use of storytelling techniques following 
from the media logic such as personification, simplification, and enhancement. If one relates this to what Kovach and Rosenstiel have defined as the elements of journalism, then there are surely reasons for concern. (Nord and Strömbäck 2003: 73)

Similarly, Carles Pont Sorribes and Sergi Cortiñas Rovira (2011: 1061-1062) fight against "defective journalistic practices" by summarizing ten recommendations aimed at "improving news coverage of risk and crisis situations by the communications media." Among other things, the authors stated that journalists "need to avoid coverage based on statements by institutional actors and persons directly affected by a crisis" or that they need "to be more rigorous and should avoid sensationalism and overly dramatizing information," without taking into consideration crisis situation as a work environment.

All in all, while Nord and Strömbäck (2003), Sorribes and Rovira (2011), and many others obviously provided their version of how a certain part of reality should look, they forbade the journalists from doing so. James rather thought that journalists have the right to do the same thing that the scientists did, namely taking a position, promoting certain values, and speaking and writing in an emotional/partial way. Moreover, if the obsolete understanding of objectivity was a part of journalistic professional ideology, shouldn't the academics rather criticize than reinforce it?

Luckily, there was a critique of the ideology, coming from both scholars and professional journalists. The one-dimensional notion of objectivity has been criticized for ignoring the journalists' point of view and for working as an object of desire that is impossible to reach, rather than as a practice (Carpentier and Trioen 2010; Post 2015). Objective reporting remains an unattainable point on the horizon: "the ideological construct of objectivity can never be fully captured by [the everyday journalistic] practices. These practices will always evade and escape the ideological lure of the concept of objectivity" (Carpentier and Trioen 2010: 317). (Feminist) media scholars have argued that, contrary to the professional mythology surrounding traditional journalism, subjectivity and its various manifestations do not contradict objectivity. Both values are constitutive and necessary elements of journalists' professional identities (Van Zoonen 1998).

Corresponding to this "affective turn" in journalism and media studies (Richards and Rees 2011), media professionals' attitudes toward the norms of reporting have begun to change (Tumber 2011). Emotions have 
become more acceptable within the recent mainstream of 'hard' journalism. Proponents of non-mainstream successors to the New Journalism of the 1960s- "narrative," "literary," or "attached" approaches (see e.g. Harbers and Broersma 2014; Pauly 2014; Ruigrok 2008) have also advocated openly emotional journalistic discourses that would lead to repositioning of the author and the reader. These journalisms seek to "capture social complexity in all its richness and nuance, and to celebrate the integrity and cultural authority of the individual reporter" (Pauly 2014: 590) and thus reject the traditional "contrived" display of objectivity. Thus, narrative journalists are not supposed to stay detached; they are invited to view and describe reality through the lens of their feelings, thoughts, and experiences (Harbers and Broersma 2014). In this sense, such emotive practices conflict with the objectivity regime, which is given up for the sake of morality and ethical journalism.

James' colleagues' thoughts proved that the critique of the objectivist notion of professionalism was, indeed, alive and well. Apart from Positivists, who still had the normative studies in their mind, there were more experienced Measurers and, primarily, Franks, whose view that "emotions are one of the facts" (Lotte) best concurred with the opinion that reporters' emotions are a legitimate part of their work. The existence of Measurers and Franks proves that the practice of crisis reporters' emotional management and their experience is shaped not only by the traditional version of journalistic professional ideology but also by its critique, which allows for diverse emotional styles (Peters 2011). Thus, if they stay within the boundaries of quality journalism, crisis reporters can choose the extent to which they let in their "authentic" emotional experience; they have a certain limited freedom in their emotional management (Illouz 2007).

However, it is necessary to stress that rather than following a certain specific stream of attached or literary journalism, the majority of the reporters simply understood emotions as an integral part of the general journalism they performed. Rather than embodying the rise of various "new journalisms," most of the reporters exemplified the increasing normalness of emotion in mainstream news (Pantti 2010; Wahl-Jorgensen 2013). Thus, their views concur, for example, with Glück's reconceptualization of a "good journalist" as one who includes empathy among her professional skills (Glück 2016). Judith articulated this very clearly when she emphasized, "I use myself as a person, I use empathy, I use my personal skills." Similarly, Glück's interviewees, British and Indian jour- 
nalists, stressed the importance of empathy and its various dimensions for journalistic storytelling and a successful journalistic career. Their empathy was converted into emotional capital. Such use of one's empathy, transforming personal skills to emotional capital, is one type of journalists' emotional labor, that is, it is immaterial labor that is linked to the precariousness of cultural and information work in general (Hesmondhalgh and Baker 2011).

Combining subjectivity and objectivity, integrating personal and professional identities, may be more typical to topics that alter journalists' perception of their own role (shifting it from purely informational to explanatory, or even educative), such as environmental issues (Tong 2015), children's death (Glück 2016), or terrorism. The case of September 11 provides many examples of shifting norms and practices: "Much reporting after September 11 turned toward a prose of solidarity rather than a prose of information" (Schudson 2011: 49). During and after a terrorist attack, journalistic values and roles can thus differ from impartiality and informing. As Morten Skovsgaard et al. (2013: 38) claim, objectivity is not carved in stone or interpreted uniformly as a norm excluding emotions; rather, "the objectivity norm is open for interpretation ..., related to role perception in different journalistic cultures and under different circumstances."

Therefore, crisis circumstances challenge the notion of objectivity as a cornerstone of journalistic professionalism. Rather than seeing the more or less detached, neutral version of objectivity as the fixed essence of good journalism, especially after September 11, journalistic professionalism could be defined by journalists' prudence (Champy 2009): by their ability to weigh a particular situation in its complexity and make decisions that help them to realize the values and fulfill their roles in the best possible way. In practice, the prudence can mean engaging with the still dominant imperative of objectivity more creatively, embracing "a more diverse and multiperspectival journalism" (Deuze 2019: 132) based on uniqueness of each (crisis) situation and context in general.

Moreover, as some of James' colleagues-Nicolas, Jesse, Giuseppe, Bob, and Lotte-said, the way of using one's emotions in the newsmaking process influences whether one becomes a Cynic, a Stoic, or a Broken ("Everybody knows it's a bad idea to keep it very much for yourself," said Bob), because the freedom of emotional expression shapes the overall experience (Giuseppe). 


\section{Professional Ideology and Cynicisms}

In turn, the emotional styles are further entangled with professional performance:

Don't misunderstand me, as if I was just some cynical bastard, thinking technically at such moments [as March 22] —which is not the case, of course. But we have, here in our newsroom-in all the newsrooms-there is an issue of digital versus paper. Which is not so easy to solve, because there's a difference in deadlines and time. So the digital news, you have to have it now and you have to have it first. ... It's even more difficult to do both. To have a digital constant deadline and a classical evening deadline, newspaper deadline. So this is ... a technical problem that we. ...... Then you have this event, and suddenly. ... ... Because all these issues that were so difficult to tackle on a normal day, they were just solved. And, of course, that's very simple, such an event is easy news. (Jacob)

A certain form of emotional numbness and cynicism, enabling, facilitating or requiring the focus on factual accuracy and technological processing of information, was seen as a personal must, and as a perfect prerequisite for journalistic professionalism (as Josef said, "I have the advantage that I am a bit retarded so I always begin to realize it later."). In this sense, the cynical ideology (Sloterdijk 1987) forms a vital part of the journalist's professional ideology. "[T]he ability of [the cynical ideology's] bearers to work-in spite of anything that might happen, and especially, after anything that might happen" (Sloterdijk 1987: 5) perfectly fits into journalists' sensemaking of their professionalism: journalists are "neutral, objective, fair and (thus) credible" and "have a sense of immediacy" (Deuze 2005: 448-449).

On the other hand, as explained above, modern cynicism is an ideology and a social phenomenon from which human aspiration is lacking. The modern cynic is apathetic, refuses to engage with the world, and is resigned to her experience of alienation (Bewes 1997; Navia 1996; Sloterdijk 1987). This position contradicts journalists' professional ideology. Professional journalists "have sense of ethics and legitimacy" and "provide a public service": they "share a sense of 'doing it for the public,' of working as some kind of representative watchdog of the status quo in the name of people" (Deuze 2005: 447-449). Thus, some of James' colleagues understood ideological cynicism as not only a psychological danger similar to other psychological threats but also a threat to professionalism: 
The notion of public service journalism means that we never falsely dramatize things. It's about being precise in the description. And at the same time, in the routine we can't - that happens to people as well—slide into a cynical approach, by overlooking things and so on, see? What I've witnessed as well, that people, being burntout, didn't give a damn, a refugee wave didn't motivate them to write a precise headline and they cut the topic dead. (...) So burnout and the related cynicism threaten journalism. (Marek)

Apart from Marek's concern that cynicism goes hand in hand with losing one's motivation to be accurate, cynicism was also dangerous in terms of losing one's ability to empathize and be affected-which is a necessary skill for a good, responsible journalist (Bob, Lilah, Judith; Glück 2016; see the more thorough criticism in the section "Cynics and Kynics: Pissing Against the Idealist Wind"). Becoming too cynical, the critical reporters thought, could mean turning into a vulture.

In short, journalists' professional ideology is self-contradictory, pointing to the already mentioned actor/observer paradox (AndénPapadopoulos and Pantti 2013; Richards and Rees 2011). On one hand, the ideology requires that journalists accept the position of ideological cynics, stay neutral and detached, and be able to work under any circumstances. On the other hand, the ideology implies their moral and political involvement in the community. Even pointing out the inner inconsistency of journalists' professional ideology, however, does not diminish its strength: "The point is that the embrace, rejection as well as critical reappraisal of objectivity all help to keep it alive as an ideological cornerstone of journalism" (Deuze 2005: 448).

So much for ideologies and journalists' self-definitions. It was almost time to touch ground and James had not yet finished his preparations.

\section{"You Can't Leave Your Journalists Alone with Their Feelings": Organizational Identities}

The reporters' emotional experience was also influenced by the technology of power circulating within the media organizations (partly, but not fully overlapping with the power of professional ideology) conducting individual action. To be sure, power, in Foucault's view, is neither owned by nor a base of institutions (such as the media); rather, the latter presuppose, capture, organize, and reproduce it (Foucault 1978). In particular, media organizations reproduced and organized the power over journalists' emotions through the positioning of individuals within the organizational 
hierarchy and through official meetings but also through the constantly occurring micro-moments reminding the employees-or the falsely selfemployed - of their tasks and responsibilities.

The organizational technologies of power over journalists' emotions were specific and had varying effects in each of the media organizations, since the influence of such technologies always depended on a strategy being pursued by the media and, primarily, on the concrete people who worked in both leading and ordinary positions.

At $\operatorname{VRT}$ (both the radio station and television channel) and some other media such as $D R, I, I G$, and in $C R$, the way of working with emotions was allegedly left to the individual reporters. It is necessary to mention that the people James knew at the organizations were established "brands"-strong personalities with established individual agendas and distinct viewpoints familiar to the public:

If I am shocked because I see something, I wanna say I am shocked. I have seen a lot. You know, the Belgian public knows me a little bit. And I think when I say I've seen so many things, I am shocked by seeing this, it says something to the public. So I think it's ok to say that. (Lotte)

When I was in Libya, in the first days, I did a lot of reporting on all the casualties that were going on. And I remember that I did an early morning report. And so the first sound you could hear on the radio was the clapping shut of the coffins for all the dead people. You could hear on the radio the flies, flying over the dead bodies. And afterwards we had a discussion at work, and they said, wow, that was very cruel, because you could hear the flies. I said, yeah, but what do you expect, it's Libya, it's August, it's 40 degrees, there is no power, people die. This is what you see! ... let them hear how it is. Let them hear how it is. Dead people on the streets in 40 degrees. This is how it sounds. That's the way of emotional reporting. (Jesse)

The organizational identity of experienced parachutists gave them more freedom of emotional expression. On the other hand, the same renowned reporters, often holding the position of opinion-makers, felt intense political pressure "to keep it in the middle" (Sam) in terms of opinions and emotionality. (Sam spoke about campaigns to have him fired; Lotte used to receive a lot of criticism via e-mail and social networking sites.)

The respect for the individual, personalized reporting of well-known correspondents and parachutists was similar at $\check{C} T$. The editors (in chief) did not strongly intervene in the ways reporters chose to manage their 
emotions and use them in news (Čestmír, Marie), and the reporters felt free to lard reports with their indexical feelings (Vítek). As Marie said, it was because most of the reporters had "encoded" or internalized the work with emotions, in such a way that the editors and editors-in-chief did not need to intervene, except in excessive cases (such as overly political reports or very brutal footage of Daesh).

Nevertheless, at main meetings, the heads of $\check{C} T$ news explicitly weighed-and pushed for-visual and informational proportionality, accuracy, and quality of concrete shots and they criticized technological mistakes and so on. This is to say that the leadership was more interested in procedures and technologies of production and sign systems than in emotions. By preferring certain visual and narrative representations over others, the bosses were not only advancing specific crisis visualizations and signification (see McDonald and Lawrence 2004) but also valorizing the crisis (Van Loon 2002).

James minimized the video of Viggo and found a file called "Manual for breaking news" on the desktop. He double-clicked on the icon. It was two pages of rather detailed instructions for the whole $\check{C} T$ organization. James read the first few lines (Image 4.4).

\section{Manual for BREAKING NEWS}

\section{FLASH NEWS - Broadcasting by a matter of minutes}

1) The news is announced by the yellow crawl (responsibility of a graphic editor)

2) The news is announced by the host at the first opportunity (responsibility of the news editor)

2a) If there is no verified or detailed information, the host, during regular broadcasting, returns to the event verbally and repeats the basic message (responsibility of the head of broadcast)

BREAKING NEWS - Broadcasting by a matter of tens of minutes - host, respondent/s, editor

Image 4.4 Czech Television's manual for breaking news obtained during the fieldwork, Autumn 2015, translated from Czech by the author. Screenshot of the Word document taken by the author 
He scrolled through the rest of the file and saw there were only practical and technological guidelines. No mention of emotions whatsoever.

A similar focus on technologies of production, along with analogous internalization of the balance between hard facts and emotion, was apparent at $L S$ :

[You can tell your boss, I want this story on the top of the page. ... But you never discuss the balance between fact and emotion. Because you know that most of the time it's $90 \%$ fact, $10 \%$ emotion. That's it. (Nicolas)

However, one of Nicolas' bosses, Louis, did not agree that there is no managerial strategy influencing journalists' emotional work:

You can't leave your journalists alone with their feelings. I think. It's very important to constantly communicate about the way you are telling the news. I think it's very important. ... it's more a managerial problem. (Louis)

Louis further explained that journalists must be constantly reminded of their audience: who are the readers, what they expect, and that journalists actually write for the readers. Louis' acts of translation of the economic factors of making crisis news into the individual journalistic practices clearly illustrate the entanglement of technologies of power and production (and also technologies of sign systems and the self; Foucault 1988).

The technology of power coming with (from and through) the economic pressure on the media organization was apparent also at $L N$, another commercial newspaper. At first sight, the foreign affairs authors enjoyed considerable freedom, because the owner-Andrej Babiš, the then Czech finance minister and oligarch controlling significant parts of the Czech media, agriculture, and other markets- “doesn't know that foreign affairs exist. He would notice only if Ukrainian rape penetrated the Czech market" (one of the $L N$ reporters). Indeed: when James worked for $L N$, he felt as free as a bird in choosing his topics and his writing style, and his adept colleagues enjoyed even more autonomy.

On the other hand, the alpha and omega of all newspaper content is advertisements. The number and length of articles and the layout of each page often had to be adjusted to advertising. It was not unusual for the journalists to re-structure the "World" pages because of modifications in advertising. It sometimes meant significant changes-typically abridging-to the international news section: 
We have to re-structure the whole page due to the placement of the advertisement. The girl from Syria is out. It's a pity, Astrid says, but the terror attacks in Thailand are important, because people from Czechia often go there on holiday. (Field notes)

The criteria for keeping or leaving out a topic were international importance, relevance for Czech readers, variety, but primarily the interest of one of the gatekeepers (the bosses/the head of the foreign affairs section) (cf. Harcup and O’Neill 2001).

The economic factors could also be the reason why the superiors criticized articles that were "activist" (see the section "Moral Dilemmas and Guilt"). In short, there was the instruction "to make it balanced." Furthermore, the readers of $L N$ expected quality graphics and sensitive work with words and images.

The same was true for another commercial daily, $D M$. Crisis reporting at $D M$ combined the emphasis on the individual styles of concrete journalistic personalities with consideration of readers' preferences. This meant that the way of working with one's emotions was partly "a choice you have to make as a journalist" (Sven), but partly something imposed:

[a] difficult question that I need to deal with myself is the balance between the kind of distance that your readers expect from you and also the kind of emotional involvement that the same readers also expect from you. (Jacob)

In practice, the difficult questions and choices often resulted in creative solutions (e.g. illustrations instead of images of victims), and also very careful, sensitive reporting that was close to the notion of peace journalism: a nonviolent approach to cover conflicts, stressing the moderating influence of media during times of conflict (Neumann and Fahmy 2016), similar to the VRT's strategy of "constructiveness" (mentioned in the section "Crisis Is Media-Constructed Is Real").

Despite the specifics of different media organizations, there were some shared ways in which the power circulating within, and organized by, the media influenced the journalists' emotional experience. The power simply pushed the reporters to treat the tragedies and suffering of others as a professional task, to make news, and to make the news fast:

"Why isn't it now? We must do these things immediately, not to wait half an hour!” (Field notes; Čestmír, scolding his subordinates for not having a piece of news ready on a bomb on a Russian aeroplane) 
The journalists had to "do the job in any case, whatever happens ... it's impossible not to do it" (Matouš); to be at work constantly- "But it's normal. It's a crisis time, so you've got to be there constantly" (Louis); to re-conceive the border between personal and professional time.

In principle, the universal organizational technologies of power over journalists' bodies meant that if rough, raw, genuine, personal emotions did not in any way enhance the news or even had a disturbing potential, then they did not have any place in the workplace during working hours. The emotions had to be policed, disciplined, refined, and polished, which applied also to the freelancers: if they wanted to publish in a particular medium, they needed to accommodate themselves to their established style, or, as Farrukh put it, to "buy their myth."

As described in the previous chapter, the need to constantly handle, postpone, suppress, or utilize one's emotions can result in the development of the Cynic, the Stoic, or the Broken emotional styles (Hochschild 1983; Illouz 2007); or, the Cynics', the Stoics', and the Brokens' emotional styles are formed by the technologies of power circulating within the media organizations (Foucault 1988). This power does not prohibit the use of emotions, reject personal involvement, completely suppress emotional experience, or ban the journalists from feeling compassion for the unlucky. Rather, the power controls, optimizes, orders, and organizes the subjects' emotions (Foucault 1978; Rayner 2001). The (bio-)power brings "life and its mechanisms into the realm of explicit calculations" (Foucault 1978: 143): measures them, objectifies them, and sets them into productive coordination, so that they may operate as one wishes (Rayner 2001).

In other words, the Cynics, the Stoics, and the Brokens are organizational, economic identities: subjects constructed within the relations of work and organization (Du Gay 1996). For Cynics, Stoics, and Brokens, emotions - one of the most intrinsic properties of a living human being (see Illouz 2007; Rosaldo 1984) — have been stripped of their indexicality and the competence to handle them has been translated into professional advancement, that is, social and economic benefits. To be a good, respected, and professional journalist within a media organization simply requires accepting the inherent precariousness related to the emotional labor, turning one's emotions and emotional styles into currency, evaluating and commodifying them (Hochschild 1983; Illouz 2007; Peters 2011).

Yet, the crisis regime did not need to constantly nag the journalists to keep cool. On the contrary, as mentioned above, during crisis times, "Everybody was ready to give a helping hand" (Jacob, speaking about 
reporting on the terror attacks in Brussels), because everybody had internalized or "encoded" the proper way of handling their emotions (Marie, Nicolas):

It must be these extraordinary things, and in the moment I feel that the management doesn't need to push the people to make [the news] look better. The people want it themselves. In this sense, Charlie Hebdo was typical. (Viktor)

\section{Technologies of the Self}

James got up and went to the toilet. After two minutes of jiggling the handle, he gave up. The more humane flight attendant dashed by, throwing in that "the toilets are out of order." Persuading himself that he did not have to go, James lowered his head and went back to his seat. Luckily, his flight toward the perilous catastrophe was drawing to an end.

He sought comfort in technologies of the self. Foucault defines technologies of the self as a matrix of practical reason

which permit[s] individuals to effect by their own means or with the help of others a certain number of operations on their own bodies and souls, thoughts, conduct and way of being, so as to transform themselves in order to attain a certain state of happiness, purity, wisdom, perfection, or immortality. (Foucault 1988: 18)

In media organizations, technologies of the self and technologies of power were almost undistinguishable: "under the regime of enterprise, technologies of power ... and technologies of the self ... are imperceptibly merged" (Du Gay 1996: 137-138). Self-realization, personal responsibility and emotional accountability, self-direction, and self-management become not only economically desirable but also personally attractive. As Eva Illouz (2007: 114) writes, the difficulty of clearly distinguishing between the economic and emotional register of action may mark a new stage of capitalist culture, demanding a united economic-emotional self. The interconnection of professional/organizational and personal, as strictly expressed in Paul Du Gay's statement that "Becoming a better worker is the same thing as becoming a better self" (Du Gay 1996: 137), was illustrated by Vitek's remark that "when a human is a better human, it certainly makes him a better journalist" (see also the section "Parenting"), meaning that psychosocial maturity and holding the correct values is ben- 
eficial for professional, organizational identity. In this sense, technologies of the journalistic self are inseparable from organizational power.

In terms of precarity, the technologies of the self carry out the conversion of precarization and exploitation into self-precarization and selfexploitation, so typical for creative professionals (Banks 2007; Lorey 2011). The reporters, with their desire for experience, recognition, and self-realization, adopt the power of their professional ideology and organization and exercise it over their very selves: accepting precarious working conditions as inevitable and unchangeable, obediently taking risks without questioning that it is outsourced to them, and performing potentially harmful emotional labor.

How did the technologies of the self shape the journalists' emotional experience of crisis?

To put it simply, the emotional styles, organizational identities (Du Gay 1996), and economic-emotional selves (Illouz 2007) of the Cynics, the Stoics, and the Brokens were less outcomes of immediate external pressures than outcomes of hard work on their selves: results of "crafting" the experience of involvement, of "finding the right balance of disengagement and nonchalance" (Peters 2011: 303), finding the "right distance" (Bernard 2008; Castra 2004; Molinier 2009). The merging of technologies of power and technologies of the self together with the commodification of emotions means that the line between the media organization and the self becomes blurred. In the end, the journalists feel, perceive, and think largely through the lens of their organizational identity:

I am there because I am supposed to work there, see? And it determines the experience. (Kryštof)

\section{Looking Through an Ideal Screen}

The technologies of the self-the operations effected by the journalists' own means on their own thoughts, bodies, conduct, and ways of beingled to a state in which the journalists looked at crises through the lens of an ideal screen, that is, weighed primarily or exclusively the journalistic potential of the crisis event and its individual aspects:

When [a crisis happens], I am oblivious to it. Or, I feel what is good for the report and what is not. I draw a line between what to put there and not. (Ester) 
Some of James' colleagues kept using the same lens even while not at work, like Pavel, who recalled that after the terrorist attacks in Paris in November 2015, he was primarily thinking about how his colleagues "processed" the attacks for broadcasting, how they reacted professionally; how they "worked it out." The tendency to look at things exclusively from the professional and technological perspective was typical for television reporters who, even in the moments of facing suffering and tragedies, considered the future appearance of the crisis event on a screen:

The person that one is shooting may be in a bad situation, but at the moment of shooting, one thinks of getting good images, and whether the person speaks in an interesting way. (...) There is an element of vulturism in it. (...) So one decides, in a split second, should I shoot it or not? ... Because it's terribly illustrative of what happens there. But from the humane perspective, it's debatable. (Matouš)

Again, not only the perception but also the rational considerations were directly and explicitly driven by the logic of the media organizations, such as accepted journalistic codes and the reporters' notion of professionalism and ethics: what the television "can" and "is allowed to" show the viewer. One day, for example, Ester was working on a report on the Syrian war, using images of people tortured to death, when she told James:

I look at it and don't think in the way 'Jesus Christ, it's a human being with a smashed skull,' but I tell to myself, 'I won't use this one, because it's too much-I need a picture in which he is broken, but less broken.' (Ester)

There was often an aestheticizing tone to these thorough considerations. Especially the heads and editors-in-chief, when they gathered at meetings, regularly spoke about "beautiful" or "nice" pictures of conflict, terrorism, refugees' suffering, and pietistic acts, thus perceiving the world through the lens of an ideal screen (Sontag 2003; see the section of the same name):

According to Martin, by now the memorials, flowers and candles are boring. ... Then, Martin suggests making a report about immediate police interventions: "I saw pictures from Time, nice footage, how the bullets spark, nice shots, so if something as pretty would come off...." He stresses the closeups, the colourfulness; the visual is obviously important. (Field notes) 
Martin encourages all to "try to make it like a crime story, put many live cameras there, stuff it there, I really liked it." (Field notes)

The aestheticizing mode of editors' thinking through crises-that is, considering the aesthetic aspects and thus their economic value, turning them into spectacle which was so harshly criticized by Farrukh or Bobcorresponded with framing processes: in this case pasting terrorism into a slightly fictional crime frame or defining the Paris attacks as a crime. As previous research has indicated, Norwegian coverage of September 11 resembled crime news as well (Falkheimer and Olsson 2015; McDonald and Lawrence 2004). A temperament of aestheticism, sometimes verging on nihilism, is one way modern cynicism can appear (Bewes 1997).

Seeing crisis events exclusively, mainly or partly through the lens of the reporters' profession was not limited to witnessing from a distance. Jesse, being asked about the attacks in his own country, gave a smile of apology and said that on March 22 he was in Egypt:

Q: And how did it feel to be far from here?

Jesse: As a journalist, it was very frustrating. ... Because you wanna be where the news is. Especially as a conflict reporter. I always go to the places where things happen. (...) Yes, of course, as a journalist, you think, oh God, I should be in Brussels.

Jesse's narration well illustrates the inseparability of the media organization from the journalistic self (Du Gay 1996; Illouz 2007; Van Zoonen 1998).

\section{Information and Linguistics}

Apart from the focus on the visual and aesthetic, adopting the technological lens manifested itself in the reporters' and managers' immersion in the factual and technological/linguistic details of (reporting on) crises.

First, the reporters and editors expressed a strong commitment to informing the audience accurately (i.e. transmitting to the public only information verified by multiple credible sources with good reputations), and quickly, as these qualities formed their professional ideology (Deuze 2005):

A reporter, Ella, and two editors (Marie and Václav), discuss where the fence that the story is supposed to report on is: "It is on the Macedonian-Greek border!" "No, on the Serbian-Hungarian border!" "No, on the Macedonian- 
Greek border," Ella says. She had written the headline and Václav changed it. Marie supports Ella and says a screen should be made, depicting graphically when and where the anti-immigration fences have been built. She is waving her arms in the air: "And they built it first here, then here, then here." (Field notes)

Second, all the little aspects of the tragic events were being constantly picked over and dissected from the technological and linguistic points of view. How to name the act of destroying people's lives? Is "killing," "murdering," or "executing" the most suitable word? (In journalistic parlance, the police "kill" terrorists, and terrorists "murder" people-but terrorists certainly do not "execute," although they might make it seem that way.) How should the Daesh be referred to? Is this or that not too detailed and unnecessarily explicit? Should the photo of Aylan be broadcasted? ("This is what we really discussed for an hour," Čestmír said.) Are the shootings not wrongly mixed-up? Who should be invited to speak about the issue in the studio? Can the reporter on the spot manage to send the report in time?

Not only were the discussions on the factual, technological, and aesthetic aspects of reporting often mutually interlinked, like in the debate about the location of fences, but they were also often interwoven with a political dimension (see Ben-Yehuda et al. 2013; Neumann and Fahmy 2016; Van Der Meer et al. 2016).

James was becoming more and more impatient. He had scratched the last few letters of the draft of his future report, and wanted-needed-to land. He thoughtlessly, automatically clicked on another random mark of the video, and let Viggo speak. "Yes, there is a human crisis, because in today's world we can contemplate the death or the torture of a human being with the feeling of indifference. Friendly concern, scientific interest, or simple passivity." But how could James care about the suffering of others with such a job to be done at San Lorenzo and such a state of his urinary bladder? He unwittingly, anxiously looked back.

Looking back at cynical ideology (see the sections "Cynics and Kynics: Pissing Against the Idealist Wind"), the professional concentration on the aesthetic, linguistic, and technological aspects of a crisis-instead of its tragedy-seemed a case in point. But besides being an expression of the modern-cynical inauthenticity and detachment from the world, the focus on factual, technological, and aesthetic details of crises could be seen as a manifestation of a kynical commitment to truth-telling, that is, an emotionally charged sense of social and political responsibility (see the section "Professional Ideology and Cynicisms"). 


\section{Metaphor of Emotional Robots}

Getting ready to step onto the uncertain terrain of San Lorenzo, James was looking at the catastrophe more and more through the lens of The Mo. Like his colleagues, who deliberately plugged their mindful bodies into the technology of newsmaking, accepted the technological perspective, and let the environment permeate their emotions, thoughts, and feelings, up to the point that these became technologized (see Hansen 2006).

James very often noticed the inanimate ways in which his colleagues discursively constructed their own identities. They used to speak about "switching" between different types of subjectivities, such as the European and the crisis one, the personal and professional one, the normal-times one and the crisis-times one, the authentic one and the theatrical one, and so on:

My tactic is always to switch off in the head. And it's not about being cynical, it's more a defence mechanism in my head. I go somewhere, I report on it, I go back, and I'm in another room of my head. (Carl)

In the given situation, in the given culture, in what was happening there, it just worked like this. There, one simply switches to another mode and tries to immerse oneself in things that are important. (Čestmír)

I think I am quite able to switch. ... To make a switch in my head. Because you just have to see what your job is. (Lotte)

I just run in the 'affair' mode. (Olga)

You just switch yourself to the mode 'theatre' and run. (Viktor)

James also noticed that the reporters sometimes perceived the practice of switching between the different "modes" and "regimes," "turning on the professional emotions" (Marie; see Hochschild 1983), or "recharging the batteries" as more difficult than simply being in the crisis environment:

I don't have the enthusiasm, I just don't feel like doing something else again, because today I had to shift gears and change between three topics which were all enjoyable but it was during one single day. See? So this is demanding. I mean, to recharge the batteries. (Vítek) 
Such a discursive construction of the reporters' identities is not profession-specific; indeed, it is very similar to the practice of "going into robot" that Arlie Hochschild (1983: 129) noticed among flight attendants. The robotic metaphor falls into the historically deep (empiricist) and common ontological human-machine metaphor (Lakoff and Johnson 2003; see Scheper-Hughes and Lock 1987). As George Lakoff and Mark Johnson (2003) argue, a metaphor is not only a matter of language; on the contrary, the whole human conceptual system is metaphorically defined and structured. Speaking of oneself as a rechargeable and switch-off device, the authors postulate, goes hand in hand with conceiving of oneself as a segment of a gear train or a machine. Since the metaphor is systematic and coherent, it sets aside the reporters' disposition to get genuinely involved (Peters 2011) that is inconsistent with the human-machine concept.

James glanced at his favorite flight attendant at the nose and felt a wave of fellow feeling.

He recalled a few moments when the technologization of emotions was reduced to absurdity. This happened whenever the reporters thought and spoke of precisely delimited parts of their selves as of machines dissociated from other parts of their selves that were endowed with intentions and authority:

I wanted to throw up, or wanted to cry and go away and I just didn't want to be there. And I really had to pull myself together and say, Lotte, you cannot do this now, switch your button, and you just have to work now. (Lotte)

I am a journalist, but on the other hand, often I switch the button off. (Jesse)

The human mind is so clever! It builds a wall, or something. (Diego)

Sometimes, James' colleagues even spoke of themselves as particular types of machines and robots, for example Jesse, who identified journalists' sight with frames, or Čestmír, who explained the reporters' role by likening it to a "flow-through heater":

You can see like a city which is half-ruined, and then you see like a ruined city. But even then, I can still frame the picture, and know, like, this is what happens. And this is what has happened. You frame it and you start reporting on it. (Jesse) 
Well, 'flow-through heater' is a stupid expression, but simply, simply. ... One absorbs, absorbs a ... A ... An emotion, and tries to hand it over again. (Čestmír)

Contrarily, some reporters pointed out the danger and flaws of perceiving oneself in his/her wholeness as a machine and stressed the right balance between a technological and a humane approach to their work:

If you're just trying to be a machine, follow the reader, it's also very strange. But you don't react in a humane way. (Sven)

I think journalists should not be machines, but they should still report on the facts. (Jesse)

Similarly to handling their emotions on the output, the ability to achieve harmony between the machine and the humane sides of the self is something that the crisis reporters developed over time. Consider Lotte's above-mentioned experience of reporting on September 11: she was working the whole day "on automatic pilot" on the facts and images: "And you see people jumping from the World Trade Centre, but you don't realize it." According to her, not realizing it was an effect of "some kind of safety button in [her] head." But "shutting one's emotions out" cannot be practiced forever-so she learned to "let in some emotion" even while covering a crisis.

The reporters' embodiment of and plugging into the newsmaking machine that expressed itself in the ontological metaphor was thus perfectly consistent with emotional self-management: handling, suspending one's indexical emotions, disembedding them from particular actions and relationships, and substituting them in accordance with standardized speech and text patterns (Illouz 2007). What the journalists would have spontaneously felt was, within the complex of technologies of production, sign systems, power, and the self, replaced by what they were supposed to perform (cf. Hochschild 1983). The replacement, in turn, destroyed the experience of involvement (see Peters 2011): "I can play, I think I can play very good. But I must be very disconnected with this world," said Sam.

A sudden noise disturbed James' thoughts. He took his headphones off and listened to the metallic voice emanating from the speakers. "We will be landing in five minutes," the voice announced. "Please, remain fastened until the end of the flight." James was relieved, and even agog. By stealth, something or someone switched his journalist's button on. 


\section{An Overview}

James, while preparing for getting off the airplane and collecting all his devices and belongings, clearly realized that what co-shaped his colleagues' emotional styles was not only the crisis context but also the newsmaking machine, the complex of things, processes, powers, words, and actions that constituted making news.

The socio-material (Orlikowski 2007) technologies of crisis news production affected reporters' emotions in a wide variety of ways. The technologies increased the pressure on accuracy, principles, speed, precision; investment of one's personal time; danger and risk, and thus acted like an agent of precarity.

They allowed the reporters to mediate their authentic experience of the on-site presence in unprecedented ways. They could keep the journalists distant; make them cover as much as possible; allow/push them to approach the crisis scene from unprecedentedly close range, and thus place them into the scene's focal point. At the same time, the technologies were able to help the journalists overcome the stress by bringing their organizational identity (Weick 1995) to the fore.

The technologies of sign systems gave rise to Positivists, reviving and strengthening (Wiik 2015) the traditional positivist-realist version of objectivity-as-a-norm, valuing detachment, complete neutrality, and impartiality (Carpentier and Trioen 2010; Schudson 2001), arguing that crisis news should be emotionless; Measurers, carefully measuring out the "right dose" of emotions in the news; and Franks, claiming that indexical emotions are one of the facts of the story, inherent to the crisis event. Despite the variety of attitudes toward the emotionality of crisis reporting, all the groups allegedly tried to avoid melodrama and utilitarian use of emotion words. In contrast, describing one's "genuine" internal states was typically seen as professionally acceptable/profitable, morally committed, and psychologically helpful.

The way of embedding emotions in news and, in turn, experiencing crisis events, was also co- shaped by technologies of power, particularly the journalistic professional ideology and diverse media-specific managerial practices. The technologies of power merged with technologies of the self, such as self-inducing a needed mood and adopting the organizational/ professional lens (Du Gay 1996). As a result, what the journalists would have spontaneously felt was replaced by what they were supposed to perform (cf. Hochschild 1983). This replacement, in turn, weakened the experience of involvement (see Peters 2011). 
James felt a sudden increase in air pressure. The negative pressure gave his ears a shock. The airplane was about to land. He closed "The Human Crisis" and snapped his laptop shut.

\section{REFERENCES}

Adam, B. (2003). Reflexive Modernization Temporalized. Theory, Culture and Society, 20(2), 59-78.

Altamirano, M. (2014). Three Concepts for Crossing the Nature-artifice Divide: Technology, Milieu, and Machine. Foucault Studies, 17, 11-35.

Altheide, D. (2006). Terrorism and the Politics of Fear. Oxford: AltaMira Press.

Andén-Papadopoulos, K., \& Pantti, M. (2013). Re-imagining Crisis Reporting: Professional Ideology of Journalists and Citizen Eyewitness Images. Journalism, $14(7), 960-977$.

Banks, M. (2007). The Politics of Cultural Work. New York: Palgrave Macmillan. Beck, U. (1992). Risk Society: Towards a New Modernity. London: SAGE.

Beckett, C., \& Deuze, M. (2016). On the Role of Emotion in the Future of Journalism. Social Media + Society, 2016(3), 1-6.

Behrent, M. C. (2013). Foucault and Technology. History and Technology, 29(1), 54-104.

Ben-Yehuda, H., et al. (2013). When Media and World Politics Meet: Crisis Press Coverage in the Arab-Israel and East-West Conflicts. Media, War and Conflict, $6(1), 71-92$.

Bernard, J. (2008). Bonne distance et empathie dans le travail émotionnel des pompes funèbres: L'analyse des interactions en milieu professionnel. Journal des Anthropologues, 114-115, 109-128.

Berti, C. (2016, March 23). Attentats de Bruxelles: Ce n'est pas la fin, c'est le début. Le Soir. Retrieved from http://www.lesoir.be/archive/recup/1159646/article/ debats/editos/2016-03-23/attentats-bruxelles-ce-n-est-pas-fin-c-est-debut

Bewes, T. (1997). Cynicism and Postmodernity. London: Verso.

Boltanski, L. (1999). Distant Suffering: Morality, Media and Politics. Cambridge: Cambridge University Press.

Camus, A. (2016, April 4). Albert Camus' Historic Lecture, "The Human Crisis," Performed by Actor Viggo Mortensen. Open Culture. Retrieved from http:// www.openculture.com/2016/04/albert-camus-historic-lecture-the-humancrisis-performed-by-actor-viggo-mortensen.html.

Carpentier, N., \& Trioen, M. (2010). The Particularity of Objectivity: A Poststructuralist and Psychoanalytical Reading of the Gap Between Objectivity-asa-value and Objectivity-as-a- practice in the 2003 Iraqi War Coverage. Journalism, 11(3), 311-328.

Castra, M. (2004). Faire face à la mort: Réguler la "bonne distance" soignantsmalades en unité de soins palliatifs. Travail et Emploi, 97, 53-64. 
Champy, F. (2009). La Sociologie des Professions. Paris: Presses Universitaires de France.

Creech, B. (2018). Bearing the Cost to Witness: The Political Economy of Risk in Contemporary Conflict and War Reporting. Media, Culture \& Society, 40(4), 567-583.

Culler, J. (1997). Literary Theory: A Very Short Introduction. Oxford: Oxford University Press.

Czarniawska, B. (2011). Cyberfactories: How News Agencies Produce News. Northampton: Edward Elgar.

Deleuze, G. (1996). Foucault. Praha: Herrmann a synové.

Deleuze, G., \& Guattari, F. (1988). A Thousand Plateaus: Capitalism and Schizophrenia. London: Continuum.

Deuze, M. (2005). What Is Journalism? Professional Identity and Ideology of Journalists Reconsidered. Journalism, 6(4), 442-464.

Deuze, M. (2011). Media Life. Media, Culture and Society, 33(1), 137-148.

Deuze, M. (2019). On Creativity. Journalism, 20(1), 130-134.

Du Gay, P. (1996). Consumption and Identity at Work. London: SAGE.

Falkheimer, J., \& Olsson, E. K. (2015). Depoliticizing Terror: The News Framing of the Terrorist Attacks in Norway, 22 July 2011. Media, War and Conflict, $8(1), 70-85$.

Festinger, L. (1957). A Theory of Cognitive Dissonance. Stanford: Stanford University Press.

Foucault, M. (1978). The History of Sexuality: Volume I. New York: Pantheon Books. Foucault, M. (1988). Technologies of the Self. In L. H. Martin, H. Gutman, \& P. H. Hutton (Eds.), Technologies of the Self: A Seminar with Michel Foucault (pp. 16-49). London: Tavistock Publications.

Foucault, M. (2005). The Hermenentics of the Subject: Lectures at the College de France, 1981-82. New York: Palgrave Macmillan.

Giddens, A. (1991). Modernity and Self-Identity: Self and Society in the Late Modern Age. Cambridge: Polity Press.

Glück, A. (2016). What Makes a Good Journalist? Journalism Studies, $17(7), 893-903$.

Greene, R. W. (2012). Lessons from the YMCA: The Material Rhetoric of Criticism, Rhetorical Interpretation and Pastoral Power. In J. Packer \& S. B. Crofts Wiley (Eds.), Communication Matters: Materialist Approaches to Media, Mobility, and Networks (pp. 219-230). London: Routledge.

Hansen, M. (2006). Media Theory. Theory, Culture and Society, 23(2-3), 297-306.

Harbers, F., \& Broersma, M. (2014). Between Engagement and Ironic Ambiguity: Mediating Subjectivity in Narrative Journalism. Journalism, 15(5), 639-654.

Harcup, T., \& O’Neill, D. (2001). What Is News? Galtung and Ruge Revisited. Journalism Studies, 2(2), 261-280.

Hay, J. (2012). The Birth of the "Neoliberal" City and Its Media. In J. Packer \& S. B. Crofts Wiley (Eds.), Communication Matters: Materialist Approaches to Media, Mobility, and Networks (pp. 121-140). London: Routledge. 
Heidegger, M. (1977). The Question Concerning Technology and Other Essays. New York: Harper and Row.

Hesmondhalgh, D., \& Baker, S. (2011). Creative Labour: Media Work in Three Cultural Industries. London: Routledge.

Hochschild, A. R. (1983). The Managed Heart. Berkeley: University of California Press.

Høiby, M. H., \& Ottosen, R. (2015). Journalism Under Pressure: A Mapping of Editorial Policies for Journalists Covering Conflict. Oslo: Høgskolen i Oslo og Akershus.

Illouz, E. (2007). Cold Intimacies: The Making of Emotional Capitalism. Cambridge: Polity Press.

Lakoff, G., \& Johnson, M. (2003). Metaphors We Live By. Chicago: The Chicago University Press.

Latour, B. (2005). Reassembling the Social: An Introduction to Actor-NetworkTheory. Oxford: Oxford University Press.

Lievrouw, L. A. (2014). Materiality and Media in Communication and Technology Studies: An Unfinished Project. In T. Gillespie et al. (Eds.), Media Technologies: Essays on Communication, Materiality and Society (pp. 21-52). Cambridge: The MIT Press.

Lorey, I. (2011). Virtuosos of Freedom: On the Implosion of Political Virtuosity and Productive Labour. In G. Raunig, G. Ray, \& U. Wuggenig (Eds.), Critique of Creativity: Precarity, Subjectivity and Resistance in the 'Creative Industries'. London: MayFly.

Lull, J. (2007). Culture-on-Demand: Communication in a Crisis World. Oxford: Blackwell Publishing.

Massumi, B. (1995). The Autonomy of Affect. Cultural Critique, 31, 83-109.

McDonald, I. R., \& Lawrence, R. G. (2004). Filling the $24 \times 7$ News Hole: Television News Coverage Following September 11. American Behavioral Scientist, 48(3), 327-340.

Moeller, S. D. (1999). Compassion Fatigue: How the Media Sell Disease, Famine, War and Death. London: Routledge.

Molinier, P. (2009). Temps professionnel et temps personnel des travailleuses du care: Perméabilité ou clivage? Les aléas de la "bonne distance". Temporalités, 9, 1-14.

Navia, L. E. (1996). ClassicalCynicism: A CriticalStudy. London: Greenwood Press.

Neumann, R., \& Fahmy, S. (2016). Measuring Journalistic Peace/War Performance: An Exploratory Study of Crisis Reporters' Attitudes and Perceptions. International Communication Gazette, 78(3), 223-246.

Nord, L. W., \& Strömbäck, J. (2003). Making Sense of Different Types of Crises: A Study of the Swedish Media Coverage of the Terror Attacks Against the United States and the U.S. Attacks in Afghanistan. Press/Politics, 8(4), 54-75.

Nord, L. W., \& Strömbäck, J. (2006). Reporting More, Informing Less: A Comparison of the Swedish Media Coverage of September 11 and the Wars in Afghanistan and Iraq. Journalism, 7(1), 85-110. 
Olsson, E. K., \& Nord, L. W. (2015). Paving the Way for Crisis Exploitation: The Role of Journalistic Styles and Standards. Journalism, 16(3), 341-358.

Orlikowski, W. J. (2007). Sociomaterial Practices: Exploring Technology at Work. Organization Studies, 28(9), 1435-1448.

Packer, J., \& Crofts Wiley, S. B. (2012). Introduction: The Materiality of Communication. In J. Packer \& S. B. Crofts Wiley (Eds.), Communication Matters: Materialist Approaches to Media, Mobility, and Networks (pp. 3-16). London: Routledge.

Pang, A. (2013). Social Media Hype in Times of Crises: Nature Characteristics and Impact on Organizations. Asia Pacific Media Educator, 23(2), 309-336.

Pantti, M. (2010). The Value of Emotion: An Examination of Television Journalists' Notions on Emotionality. European Journal of Communication, 25, 168-181. https://doi.org/10.1177/0267323110363653.

Parikka, J. (2010). Insect Media: An Archaeology of Animals and Technology. Minneapolis: University of Minnesota Press.

Pauly, J. J. (2014). The New Journalism and the Struggle for Interpretation. Journalism, 15(5), 589-604.

Pedelty, M. (1995). War Stories: The Culture of Foreign Correspondents. London: Routledge.

Peters, C. (2011). Emotion Aside or Emotional Side? Crafting an 'Experience of Involvement' in the News. Journalism, 12(3), 297-316.

Plaisance, P. L., \& Skewes, E. A. (2003). Personal and Professional Dimensions of News Work: Exploring the Link Between Journalists' Values and Roles. Journalism and Mass Communication Quarterly, 80(4), 833-848.

Post, S. (2015). Scientific Objectivity in Journalism? How Journalists and Academics Define Objectivity, Assess Its Attainability, and Rate Its Desirability. Journalism, 16(6), 730-749.

Rayner, T. (2001). Biopower and Technology: Foucault and Heidegger's Way of Thinking. Contretemps, 2, 142-156.

Richards, B., \& Rees, G. (2011). The Management of Emotion in British Journalism. Media, Culture and Society, 33(6), 851-867.

Rosaldo, M. Z. (1984). Towards an Anthropology of Self and Feeling. In R. A. Schweder \& R. A. LeVine (Eds.), Culture Theory: Essays on Mind, Self and Emotions (pp. 137-157). Cambridge: Cambridge University Press.

Ruigrok, N. (2008). Journalism of Attachment and Objectivity: Dutch Journalists and the Bosnian War. Media, War \& Conflict, 1(3), 293-313.

Scheer, M. (2012). Are Emotions a Kind of Practice (And Is That What Makes Them Have a History)? A Bourdieuian Approach to Understanding Emotion. History and Theory, 51, 193-220.

Scheper-Hughes, N., \& Lock, M. (1987). The Mindful Body: A Prolegomenon to Future Work in Medical Anthropology. Medical Anthropology Quarterly, $1(1), 6-41$.

Schudson, M. (2001). The Objectivity Norm in American Journalism. Journalism, $2(2), 149-170$. 
Schudson, M. (2011). What's Unusual About Covering Politics as Usual. In B. Zelizer \& S. Allan (Eds.), Journalism After September 11 (2nd ed., pp. 44-54). London: Routledge.

Skovsgaard, M., et al. (2013). A Reality Check: How Journalists' Role Perceptions Impact Their Implementation of the Objectivity Norm. Journalism, $14(1), 22-42$.

Sloterdijk, P. (1987). Critique of Cynical Reason. Minneapolis: University of Minnesota Press.

Sontag, S. (1977). On Photography. London: Penguin Books.

Sontag, S. (2003). Regarding the Pain of Others. New York: Picador.

Sorribes, C. P., \& Rovira, S. C. (2011). Journalistic Practice in Risk and Crisis Situations: Significant Examples from Spain. Journalism, 12(8), 1052-1066.

Steensen, S. (2017). Subjectivity as a Journalistic Ideal. In B. Kjos Fonn et al. (Eds.), Putting a Face on It: Individual Exposure and Subjectivity in Journalism (pp. 25-47). Oslo: Cappelen Damm Akademisk.

Tong, J. (2015). Being Objective with a Personal Perspective: How Environmental Journalists at Two Chinese Newspapers Articulate and Practice Objectivity. Science Communication, 37(6), 747-768.

Tumber, H. (2011). Reporting Under Fire: The Physical Safety and Emotional Welfare of Journalists. In B. Zelizer \& S. Allan (Eds.), Journalism After September 11 (2nd ed., pp. 319-334). London: Routledge.

Usher, N. (2019). Journalism's Biggest Challenge? Journalists. Journalism, 20(1), 140-143.

Van Der Meer, TGLA. et al. (2016). Disrupting Gatekeeping Practices: Journalists' Source Selection in Times of Crisis. Journalism. Epub ahead of print 16 May 2016. https://doi.org/10.1177/1464884916648095.

Van Loon, J. (2002). Risk and Technological Culture: Towards a Sociology of Virulence. London: Routledge.

Van Zoonen, L. (1998). A Professional, Unreliable, Heroic Marionette (M/F): Structure, Agency and Subjectivity in Contemporary Journalisms. European Journal of Cultural Studies, 1(1), 123-143.

Vos, T. P. (2011). 'Homo Journalisticus': Journalism Education's Role in Articulating the Objectivity Norm. Journalism, 13(4), 435-449. https://doi. org/10.1177/1464884911431374.

Wahl-Jorgensen, K. (2013). The Strategic Ritual of Emotionality: A Case Study of Pulitzer Prize- winning Articles. Journalism, 14(1), 129-145.

Wahl-Jorgensen, K. (2016). Emotion and Journalism. In T., Witschge (Ed.), The SAGE Handbook of Digital Journalism. London: SAGE Publications(pp. 128-143). Epub ahead of print. Retrieved from http://orca.cf.ac.uk/87552/.

Weick, K. E. (1995). Sensemaking in Organizations. London: SAGE.

Wiik, J. (2015). Internal Boundaries: The Stratification of the Journalistic Collective. In M. Carlson \& S. C. Lewis (Eds.), Boundaries of Journalism: Professionalism, Practices and Participation (pp. 118-133). London: Routledge. Williams, R. (1974). Television: Technology and Cultural Form. London: Fontana. 
Open Access This chapter is licensed under the terms of the Creative Commons Attribution 4.0 International License (http://creativecommons.org/licenses/ by $/ 4.0 /$ ), which permits use, sharing, adaptation, distribution and reproduction in any medium or format, as long as you give appropriate credit to the original author(s) and the source, provide a link to the Creative Commons licence and indicate if changes were made.

The images or other third party material in this chapter are included in the chapter's Creative Commons licence, unless indicated otherwise in a credit line to the material. If material is not included in the chapter's Creative Commons licence and your intended use is not permitted by statutory regulation or exceeds the permitted use, you will need to obtain permission directly from the copyright holder.

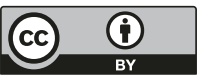

